\title{
4
}

\section{BITUMEN RIVER GALLERY - EVOLUTION AND EARLY YEARS}

Art is a Scheherazade job that goes night after night after night. The same anew. The main thing is ... don't get involved with any of this if you can think of one other thing that, in your heart, you believe is a better thing to do with your life. If you can think of another life; a lawyer, nun, brain surgeon, jet pilot, do that thing and don't get involved. Don't do it, not just because the profession is over determined but because, if you go to it as a second choice, it is going to show in your work. Your work will be second rate and you will clutter up the place with overly managed bad art. Don't do it because you want 'to express yourself'. Don't do it because you want a career. Don't do it because you feel art needs you. Don't do it if you don't need art. ${ }^{1}$

This excerpt from Noel Sheridan's essay 'Yes Tasmania', in Chameleon: a decade (1983-1993) speaks of the compulsion that, from the beginning of the 1970s, drove small groups of artists and like-minded individuals to begin setting up alternative spaces. These spaces were for artists who, excluded by various art institutions because their youth and use of media such as prints, posters, photocopies and new media precluded serious collecting, were compelled to make and show work that was socially

1 Noel Sheridan, 'Yes Tasmania', in Hammond, 1993, p 14. 
and politically relevant, on their own terms and of their own choosing. By 1980, this compulsive ethos had reached Australia's youngest city and national capital, Canberra. ${ }^{2}$

Canberra's alternative art space, Bitumen River Gallery (BRG), was not the first of Australia's alternative art spaces, nor was it modelled on those spaces that preceded it: Praxis in Perth, Australian Centre for Photography (ACP) in Sydney, Experimental Art Foundation (EAF) in Adelaide or Institute of Modern Art (IMA) in Brisbane. As national capital, Canberra differed significantly from other Australian cities and, as a result, critical differences are identifiable between the formation and early years of other art spaces and BRG.

BRG had its genesis in a small, fluid group of eight to 10 people, comprising printmakers, students from the Canberra School of Art (CSA) Printmaking Workshop, social activists, and beneficiaries of the late 1970s employment stimulus programs operating in Australia. That such a disparate group was responsible for the birth of alternative contemporary art practice can be traced to the first of these critical differences, which artist and filmmaker Tony Ayres identified as 'Canberra's subcultural homogeneity'. The second critical difference was that the formation of BRG followed on swiftly from the beginnings of Megalo in 1980. In other words, the genesis of BRG was intrinsically connected to the formation of Canberra's first printmaking collective. Its alignment with Megalo ensured that, from the first exhibition opening on 4 April 1981, the gallery's focus, while predicated on the local, would never be parochial.

By 1980 Canberra, with a population of around 220,000, began to experience a cultural divide. On one side were public servants, who managed the day-to-day affairs of the federal government; an international conclave of ambassadors and staff from a number of embassies; military personnel attached to the Royal Military College, Duntroon; academic personnel attached to The Australian National University (ANU); along with professional advisers and private business owners constituting a large service sector. It could be argued that the occupants of this side

2 Noel Sheridan (1936-2006) was the inaugural paid secretary of the EAF. By the 1980s, titles such as 'secretary' and 'coordinator', which had previously been applied to those who led Australia's alternative art spaces, had evolved to the administrative term 'director'. This change in title, although not in job description, coincided with the change from alternative art spaces to contemporary art spaces, and was a harbinger of the creeping institutionalisation of art in Australia during the 1990s.

3 Tony Ayres, 'Space', Art Network, 11, 1983, p 4. 
of the divide consumed imported culture. Broadly, the Canberra Theatre Centre (CTC) hosted interstate dance, opera and theatre companies and established artist societies held regular exhibitions at venues such as the Canberra Theatre Gallery, the Arts Council Gallery (ACG) and a number of commercial galleries around the city. Overwhelmingly, exhibitors for these events were drawn from visiting artists working in traditional areas, cultural exchange artists organised through the embassies or established artists recognised by the academy.

On the other side, although not completely in opposition, the city was experiencing growing unemployment and a steadily expanding community of students, including increasing numbers graduating from CSA. ${ }^{4}$ From within these groups came the impetus and energy that created what Ayres has described as Canberra's 'cultural fringe'. 5 Smaller cultural groups active in 1980 that drew much of their audience and many of their members from these latter groups included theatre groups such as Fools Gallery Theatre Co, Canberra Youth Theatre (CYT) and Jigsaw Theatre Company, ${ }^{6}$ dance companies and community arts groups such as Bluegum.

Ayres, an early BRG member, wrote that 1980 was:

a prosperous time for the cultural fringe in Canberra. Given Canberra's size and subcultural homogeneity, it is not surprising that all of these organisations were linked by common threads - an inter-change of personnel whose consensus of opinion substituted for stated ideology. One could fairly describe most of these ventures as politically radical, in so far as their content tended towards leftist analyses of society. ${ }^{7}$

Julian Webb, who coordinated the work of Jobless Action (the employment-creation arm of the Community Youth Support Scheme (CYSS)), played a critical role in the unfolding story of contemporary art practice in Canberra. From a base in Ainslie,

\footnotetext{
4 Indeed, many diplomatic representatives and some academics proved very sympathetic to 'fringe' art initiatives, indicating that the social divide was not entirely clear-cut.

5 Ayres, 1983, p 11.

6 Jigsaw's then artistic director, Joe Woodward, wrote, "We tended to operate on a "Collective" basis with all cast, crew and director involved in decision making and artistic responsibility. It had a strong sense of "theatre for the community" and challenging privilege and establishment values. It tried to be a door to more cooperative and social values affirming people's culture and lives' (in 'Jigsaw Theatre Company history', www.jigsawtheatre.com.au/history, accessed 11 October 2012, site discontinued).

7 Ayres, 1983, p 11.
} 
Jobless Action provided moral and physical support for unemployed people, putting together income schemes and giving 'some focus to political activism?. ${ }^{8}$

Also central to the story were the political and arts practice choices made by a small number of CSA students. CSA opened its doors in its current location on the ANU campus in 1969. In 1980, a \$3 million refurbishment program was completed. From 1978 onwards, the school had a strong printmaking focus under master printmaker Jorg Schmeisser and, critically, from the inaugural Print Workshop tutor, Mandy Martin. By 1980, Alison Alder was in her third year of a fine arts degree, majoring in printmaking. Part of an increasingly leftist, politicised youth arts scene, Alder was disenchanted with the technique-oriented master printmaker/ apprentice paradigm championed by Schmeisser and she longed for a centralised collective that devolved control into the hands of makers. At that time, no such alternative existed. 'The Art School,' wrote Alder, 'was the pivot of art activity which was closed to artists outside of that system.' She and her peers took matters into their own hands. They selfidentified as having 'high energy and high levels of political and social commitment' and, in 1980, set about changing the face of art practice in Canberra. ${ }^{10}$

Megalo was the natural outcome of a poster-making culture that put itself in the service of minority social groups. ${ }^{11}$ The poster's multiple production and wide dissemination was enabled in the 1960s through technological changes such as phototypesetting. Beginning as an underground political force in the 1960s connected with the 1968 Paris riots, poster making was legitimised through small poster collectives throughout Europe and the United States concerned predominantly with anti-Vietnam War protests,

8 Alison Alder, speech at the opening of Megalo Access Arts' new premises at the former Hackett Primary School, 1992, cited in Printing history: 18 years of Megalo Access Arts, Canberra Museum and Gallery, 1999.

9 Alder, 'Serving the needs of artists', 1983.

10 Alison Alder, interview with the author, 14 April 2010.

11 The history of poster making as art is lengthy and well documented, beginning with the work of the French poster designers Jules Chéret and Henri de Toulouse-Lautrec from the latter part of the 1800s; progressing to its use as a political propaganda tool through the twentieth century in both World War I and II and in countries including Spain, Russia and China; and produced as art objects in countries such as Japan. It is outside of the scope of this history. For the history of poster making in Australia see, for example, Roger Butler, Poster art in Australia: the streets as art galleries - walls sometimes speak (Canberra, National Gallery of Australia, 1993). Also see Therese Kenyon, Under a hot tin roof: art, passion and politics at the Tin Sheds Art Workshop (Sydney, State Library of New South Wales Press in association with Power Publications, 1995). 
feminism and the women's movement, and the anti-nuclear movement. In the 1970s in Australia, a growing political activism and awareness of these social issues, coupled with the desire of art school graduates to develop an alternative creative environment, led to the formation of a loose association of print workshops. These workshops were:

fundamentally committed to ensuring access to, and control of, information by those people whose interests and concerns are under-represented, or not represented at all, in the dominant media forms of radio, television and newspapers. ${ }^{12}$

Women's rights was the central issue for Canberra Women's Liberation (CWL), which set up a printmaking workshop in the garage of its home office at 12 Bremer Street in inner south Canberra in 1972. During 1972 and 1973, CWL members printed posters concerned with women's issues. Founding member Biff Ward remembered that member Eileen Haley 'knew a lot about' screen-printing and that CWL would have 'these big screen-printing working bees ... working really hard, printing, printing, printing. We'd print posters for meetings and public meetings and maybe demonstrations'. ${ }^{13}$

\section{The genesis of Megalo}

By 1980, printmakers in Canberra were operating as a loose underground, 'screen-printing in garages around the place, mainly producing posters to advertise events and perhaps less often to express an ideological opinion'. ${ }^{14}$ In May of that year, desire and momentum crystallised in the decision to set up a printmaking workshop. Jobless Action placed a tiny, unattributed advertisement in the Canberra Times requesting that people interested in a silk-screening collective enterprise telephone a business hours number. ${ }^{15}$ The resulting well-attended inaugural meeting included 'many strangers'. ${ }^{16}$

12 Lee-Anne Hall, 'Who is Bill Posters? An examination of six Australian socially concerned alternative print media organisations', Caper, 27, special issue, 1988, p 3.

13 Biff Ward, interview with Sara Dowse, 26 September 1998, National Library of Australia oral history typescript, 30, quoted in Julia Ryan, email to the author, 20 June 2016.

14 Alder, cited in Printing history, 1992.

15 'Silk-screening. People interested in collective enterprise ph 811702 bh', advertisement, Canberra Times, 3 May 1980, p 21.

16 Alder, cited in Printing history, 1992. 
Among those 'strangers' was Colin Little ${ }^{17}$ - who established the Earthworks Poster Company ${ }^{18}$ at the Tin Sheds, University of Sydney, in 1971 - and David Morrow, who produced work at Lucifoil in Sydney. These two brought collective experience to a group that also included Gaida Serilus, Paul Ford, Roland Manderson, Di Johnson and Webb's co-worker Annie Kavanagh. The meeting was an indication of Canberra's linked 'subcultural homogeneity'. Serilus, a 'hippie firebrand poster maker', ${ }^{19}$ was Webb's partner and Ford was Alder's. These social interconnections were critical to the formation of both Megalo and, a year later, BRG.

When Megalo received its first funding through the Department of the Capital Territory (DCT) Arts Development Fund in $1981^{20}$ it signalled the beginning of the Commonwealth's growing willingness to support emerging contemporary artists, albeit, at this time, as members of the unemployed. Muse magazine applauded the decision:

The DCT is to be congratulated on its recent funding of Jobless Action's silk screening workshop at Ainslie Village. The workshop has received $\$ 5000$ for equipment costs and is hoping to eventually employ a coordinator. Spokesperson Colin Little originally from the 'Tin Shed Collective' in Sydney told Muse that 'a major aim of the workshop was to improve the quality of poster graphics and street art in Canberra'. He saw the Village venture as a viable business capable of producing commercial posters as well as local social and non-profit prints. The collective hopes to involve the wider community by means of summer schools. ${ }^{21}$

17 Until his death on 4 October 1982, Little played an important role in the genesis and development of Megalo and BRG.

18 The Earthworks Poster Company (1971-79) became the Earthworks Poster Collective in 1972.

19 Alder, 2010.

20 ACT was funded through the Commonwealth Government's DCT until the Territory gained full self-government status in 1992. Chapters 1, 2 and 3 discuss local arts funding bodies.

21 'Museshorts', Muse, 5, p 37. This grant was the first awarded to a Canberra-based artist collective. While it was symptomatic of the increasing willingness of government funding bodies throughout Australia to support emerging artists, at this time in Canberra the focus was very much on support mechanisms for artists as members of the growing sector of unemployed, rather than as working artists. 


\section{The genesis of BRG}

As the output of political posters from Megalo screen-printers continued to increase, it rapidly became apparent that a combined shop/exhibition space was needed. At the far edge of the former St Christopher's Catholic School grounds, on the corner of Furneaux and Bougainville streets, Manuka, was a derelict building that had consecutively operated as a milk shed, a shelter shed and, finally, a bus stop. In response to a resident's suggestion $^{22}$ to local Liberal member for Canberra, John Haslem, ${ }^{23}$ that the building be used by the unemployed in some useful way, Robert Ellicott - minister for home affairs and the environment, and minister for the Capital Territory (1977-80) - handed the derelict structure over to Webb.

Alder, Ford, Webb and Serilus, together with CSA students Julia Church and Mark Denton, and Little and Morrow, had solidified their affiliations throughout the previous year with the establishment of Megalo. The shelter shed was an answer to the group's compelling need for an outlet for their screen prints. Jobless Action was closely aligned with the CYSS, and usage of the site was envisaged as a shopfront for Megalo posters and products from CYSS clients, with Jobless Action providing administrative assistance. The focus quickly turned to exhibition space, and a collective comprising Megalo members, CSA students and Jobless Action members - was formed to transform the derelict building into a gallery. The DCT expedited an electricity pole to service the building and contributed $\$ 10,000$ for urgent repairs. These included fitting a ceiling, mounting windows and doors, and replacing parts of the flooring. ${ }^{24}$

As with Megalo a year before, Jobless Action provided the official front for BRG. The focus was firmly on the unemployed and the public were advised that the gallery was run by a 'collective of unemployed people through Jobless Action, with the help of a number of committed employed people', and that it would 'sell art and some craft produced by unemployed people and other low income earners'. ${ }^{25}$

22 The resident's name was, unfortunately, not recorded.

23 John Haslem was the Liberal member for Canberra from 13 December 1975 to 8 October 1980.

24 'Future directions', a report of the Search Conference, 9 June 1985, BRG scrapbook, 1985, CCAS archives.

25 Julian Webb, 'Bill posters appreciated', Hard Times, 14, 1991. 
It was a prosaic beginning with a modest vision. The name 'Bitumen River Gallery' encapsulates a particular spirit of the time: a do-it-yourself ethos, a close-to-the-ground approach to contemporary practice in the Canberra community, a sly take on social art within a city manufactured for twentieth-century urban and suburban living. The view from the proposed new gallery took in the vast bitumen car park that serviced the St Christopher's Church and the school. In retrospect, the name constitutes a parody. Bitumen, the symbol of the urban space, remade via a youthful collective into a gallery whose existence was charged with the compulsive spirit of renewal transforming international contemporary art.

\section{Bill posters appreciated}

BRG opened on 4 April 1981 with 60 posters in an exhibition titled Bill posters appreciated. Posters came from Sydney print collectives Jura Books, Earthworks, Lucifoil, Black Earth, Toby Zoates, Cockroach, Rouge, Wimmins Warehouse, Matilda Graphics, Movement Media, Pre-Natal Press, Resistance and Shopfront Theatre; and from Breadline (Melbourne); Redback Graphix (Wollongong); Without Authority (Lismore); Red Pepper (San Francisco); and Sisterwrite (London).

The exhibition's opening image, designed by Morrow and printed by him at Megalo, featured a wide-eyed, dark-haired toddler, with the words 'Well, I've never heard of YOU either' scrolling across the bottom of the image (see Figure 7).

The national and international prints on exhibition provided a window onto contemporary social concerns, with titles including Share the shitwork (see Figure 8), Don't bomb the Pacific, El Salvador, Stop police harassment, Fight evictions, and For Aurukun and Mornington Island. 


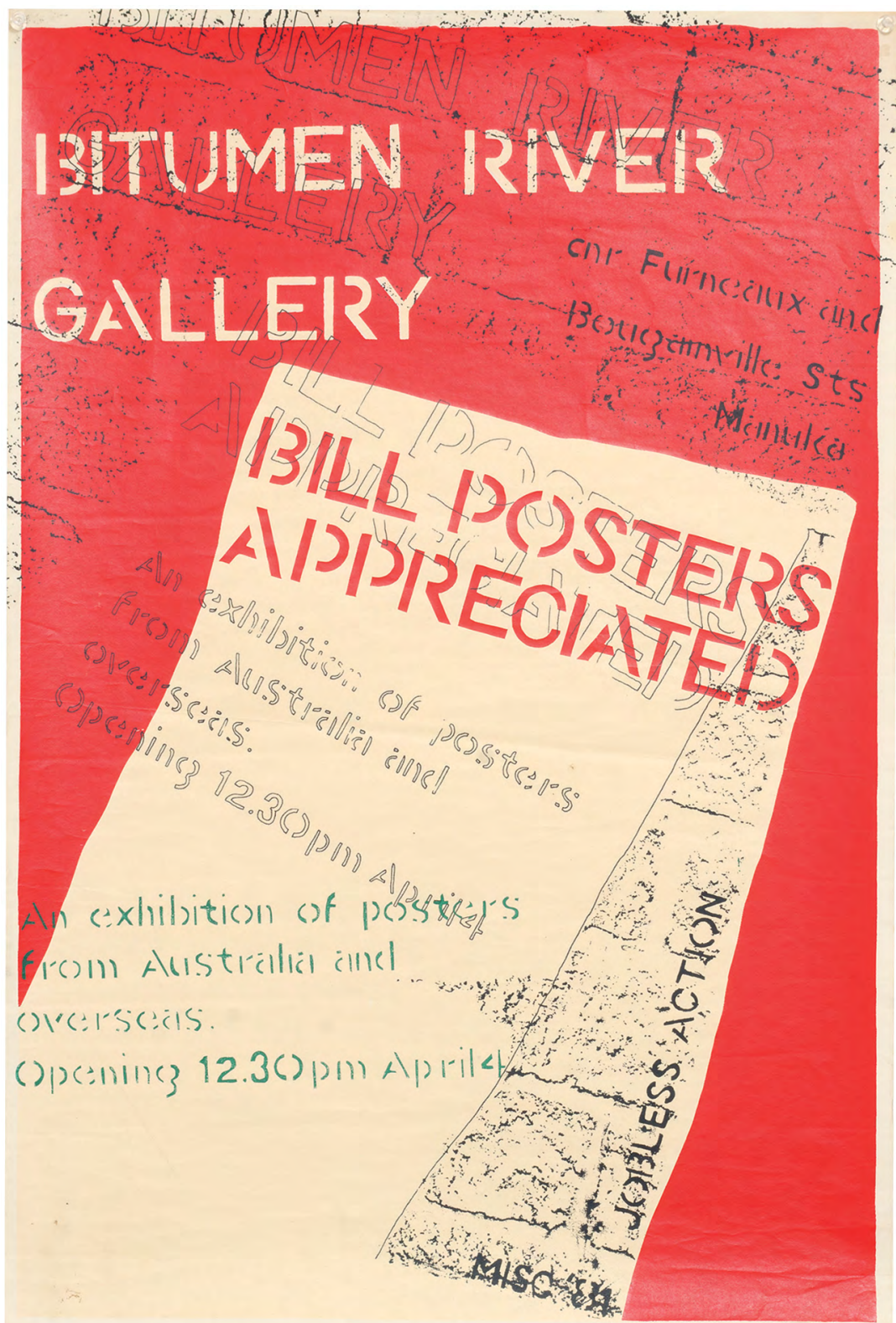

Figure 6. Bill posters appreciated, BRG opening exhibition poster, printed at Megalo, April 1981

Source. Photographer: Brenton McGeachie. CCAS image archive, reproduced with permission 


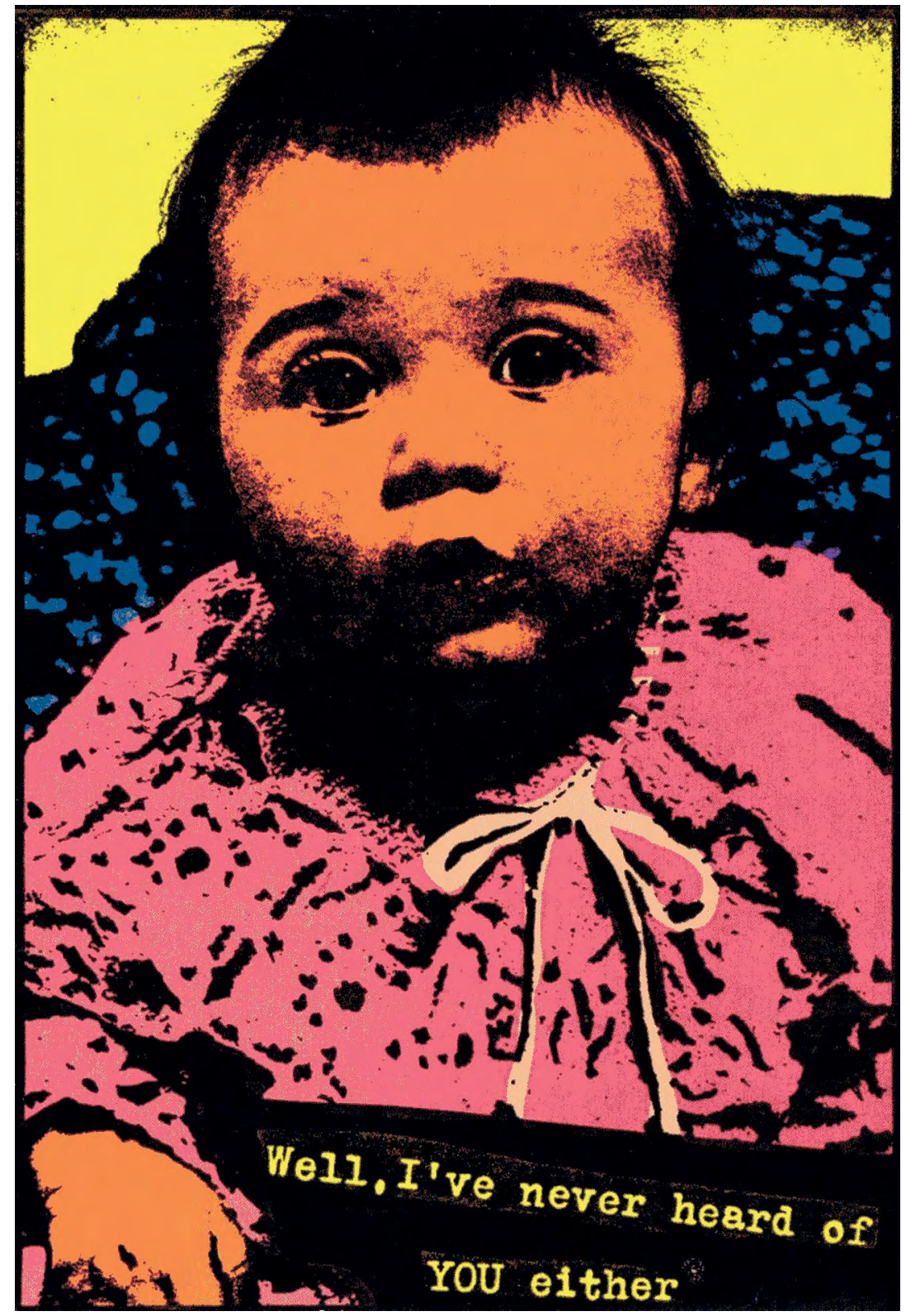

Figure 7. David Morrow, Well I've never heard of YOU either, screen print, postcard, BRG opening invitation for 4 April 1981

Source. CCAS image archive, reproduced with permission 


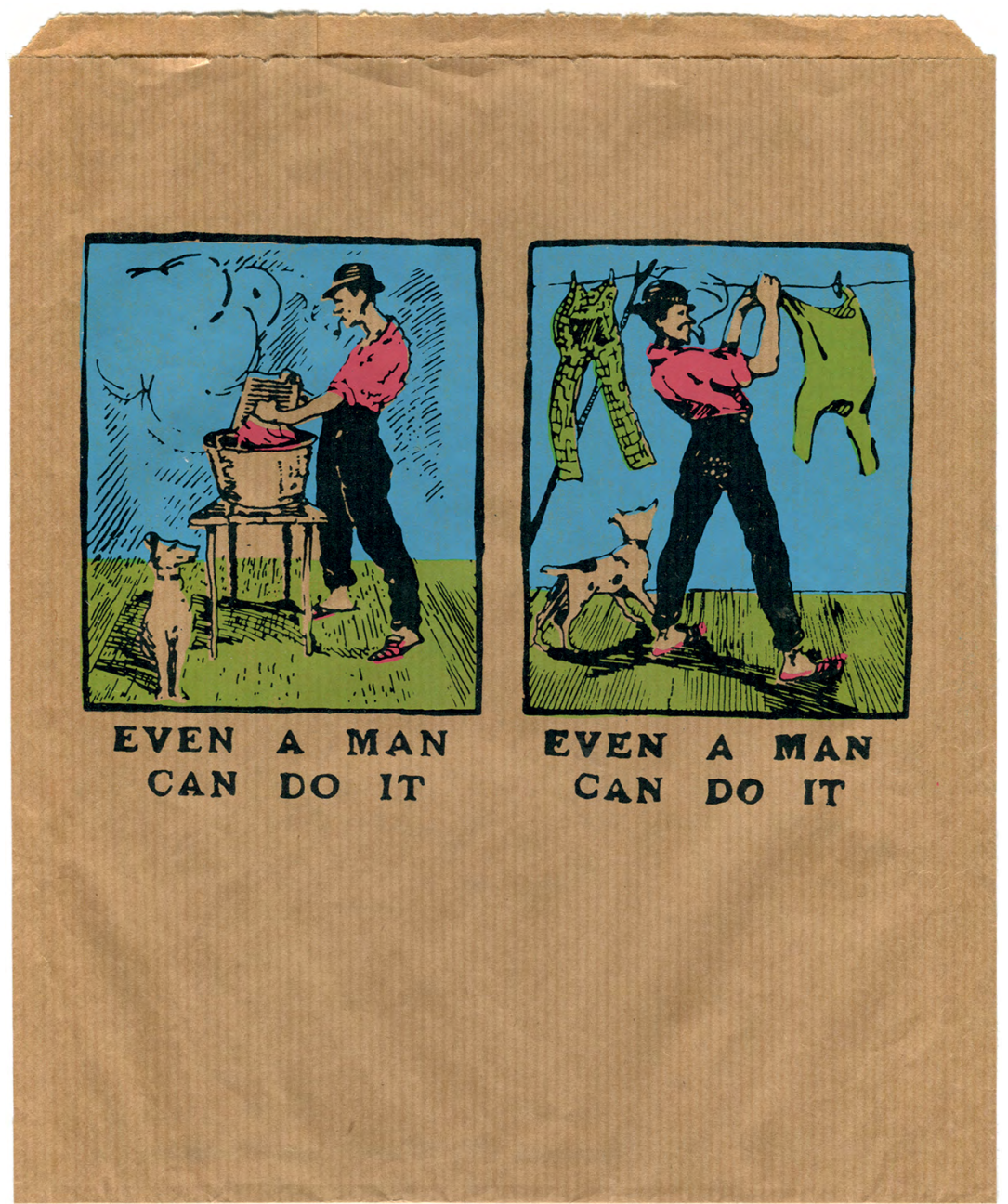

Figure 8. Alison Alder, Share the shitwork: even a man can do it, 1981, brown paper bag, screen print, $25 \times 20 \mathrm{~cm}$, Bill posters appreciated, BRG opening exhibition

Source. Photographer: Brenton McGeachie. CCAS image archive, reproduced with permission

Share the shitwork, designed by Alder and printed by her at Megalo, comprises two four-colour panels that reference early twentieth-century newspaper illustrations. The work features a lanky, hatted chap, with a pipe in his mouth and a dog at his feet. In the first panel, he is using a scrubbing board and tub and, in the second, a stick and wire clothesline. Subtitled Even a man can do $i t$, the images use crafty humour to deliver a clear message: domestic equality in the late 1970s remained as elusive as it had been in the 1930s. 
The opening exhibition was also an opportunity to make politicised statements in the press. These included an opinion piece by Webb in Hard Times, an occasional publication that was briefly produced by 'an independent autonomous collective', including Webb and 'various fringe dwellers'. Webb's review of the opening reflected the contemporary community backlash to the widening gap between the wealthy and the unemployed in Canberra. It incorporated a short thesis on the 'nature and value of work in terms other than the \$' and urged readers to support the gallery:

If the unemployed people running the place are to achieve their aim of satisfying employment, that is also paid, then your patronage is essential. If following exhibitions are of the calibre of this one then they will not be let down. ${ }^{26}$

Muse covered the opening with a statement from the exhibition's organisers that, in its impassioned political rhetoric, encapsulated a youthful, contemporary utopia:

Co-operation is an essential part of this exhibition. The building was renovated through a group effort, the posters were made under a group system. The age of individual alienation is withering ... we must oppose the terrorism of big business and its concomitant manipulative exploitation mentality; demand more humane and enduring social relationships; and develop community control of the streets and the country we/you share with all members of the world. ${ }^{27}$

The choice of Bill posters appreciated as an opening exhibition was important and prescient. It meant that, from its inception, BRG was contextualised within a national and international rubric. It heralded an intention to remain relevant within broad national and international social concerns, realising those through contemporary art practice. Posters were modestly priced at between $\$ 3$ and $\$ 4$ and embraced a wide spectrum of contemporary issues. They were overtly political, from poster number 1 , titled Dead men don't rape, through to poster number 60, titled Nuclear free Pacific. ${ }^{28}$

26 Webb, 1991.

27 'Bill posters appreciated: a statement', Muse, April 1981.

28 List of works, Bill posters appreciated, 1981-83, CCAS archive. 
From that first exhibition onwards, the gallery embraced and then transcended the local. The appellation 'parochial' would not then, or in the years to 1987, be applied to BRG, either by the public or by its members. Over the next six years, BRG members and early principal coordinators Alder together with Ford, and Virgo together with Erica Green - would continue to impress the gallery's local relevance on artists, funding bodies and the public. Importantly, they also began to align its presence with the national agenda of emerging contemporary art spaces. They did this by attending seminal national arts conferences, beginning with the second ANZART conference in Hobart, 1983; instituting a series of travelling exhibitions between Canberra, Melbourne, Perth and Hobart; leading the push for the establishment of a local chapter of the Artworkers Union and for the national Campaign for Free Admission to the newly opened ANG; and bringing in national speakers on contemporary art, such as Terry Smith, to enliven local debate and arts practice.

In many ways, despite its strong opening exhibition, BRG's continuance seemed unlikely. On the general feeling that followed Bill posters appreciated, media commentator Marcus Breen noted in April 1982:

When Humphrey McQueen ${ }^{29}$ opened the Bitumen River Gallery in 1981 with the flourish of a glue brush and the flutter of a poster, few people expected to see the gallery thriving one year later. ${ }^{30}$

To begin with, the gallery was unfunded, relying on the young, inexperienced collective members to drive its future direction and undertake day-to-day management. It was a space run, according to one local wit, 'for all lost causes of humanity'. ${ }^{31}$ In essence, it lurched through that first year, appearing to make it up as it went along, while managing to maintain a powerful, socially political focus. As Ayres would write from the perspective of 1985:

The gallery came into being with each successive exhibition; the gallery became a 'political' one because the small circle of people involved, art school graduates and under-graduates, were at that time making overtly political imagery, not through a conscious collective decision to seek out that work. ${ }^{32}$

29 Humphrey McQueen was the teacher-in-charge of 'History and appreciation of art/architecture', a one- to two-hour course for Art Diploma 1 at CSA from 1978 to 1980.

30 Marcus Breen, 'Bitumen River Gallery - one year after', Muse, 2 April - 13 May 1982, p 15.

31 Canberra and District Historical Society Newsletter, June/July 1982, p 11.

32 Tony Ayres, 'Causes: an exhibition of political posters and prints from Canberra, 1981 to 1983', Imprint, 1, 1985, np. 
Recalling the climate that marked the collective's ability to move forward, Church married the high energy levels to the do-it-yourself ethos:

We thought we had a licence to do whatever we wanted really and we kind of did. [We had] all the raw materials and that's partly what was such a charge-up about it - we could come up with the ideas, we could print the posters ourselves, we could take all the photos ourselves ... and we could also build the workshops and build the galleries ... [see Figures 9 and 10]. It was a very particular time in Australian history where people [working in the arts] did that all over the country and had done it for the generation before us too. ${ }^{33}$

The ANZART conference in Hobart in May 1983 was critical in establishing collaborative links between BRG and other artist-run spaces. Alder attended the conference, part of which included a breakaway three-day seminar, the Open sandwich conference, that brought together representatives from all Australia’s existing contemporary art spaces for the first time. They came to share with, learn from and support each other. ${ }^{34}$ The paper Alder gave at the conference provides a perspective on the volatile period immediately following the opening of BRG. She wrote:

At this time there was no real conception of how the gallery was going to operate, to the point of not knowing what the next exhibition was going to be, and a number of problems began to surface. ${ }^{35}$

Among these problems was the question of how to select future exhibitors. BRG was an open-access gallery whose only exhibition policy was that the works shown would be non-racist and non-sexist. The group had neither the experience nor the desire to make value judgements on potential exhibitors. Ford explained:

One woman said that she wanted to show - she was unemployed - so a number of us went along to look at her work and (sort of) pretend that we could decide whether she would show her work. So we all saw her work and thought, wow, what a responsibility, to say whether we like it or not and whether that person's work should be shown. ${ }^{36}$

33 Julia Church, interview with the author, 30 September 2012.

34 Pamela Zeplin, 'Crossing over: raising the ghosts of Tasman-Pacific art exchange: ANZART-inHobart, 1983', in 'Asian” media arts practice in/and Aotearoa New Zealand', New Zealand Journal of Media Studies 9, 1, 2005, nzetc.victoria.ac.nz/tm/scholarly/tei-Sch091JMS-t1-g1-t4.html, accessed 10 March 2015.

35 Alison Alder, 'Bitumen River', conference paper, Open sandwich conference, ANZART, Hobart, May 1983.

36 Breen, 1982, p 7. 


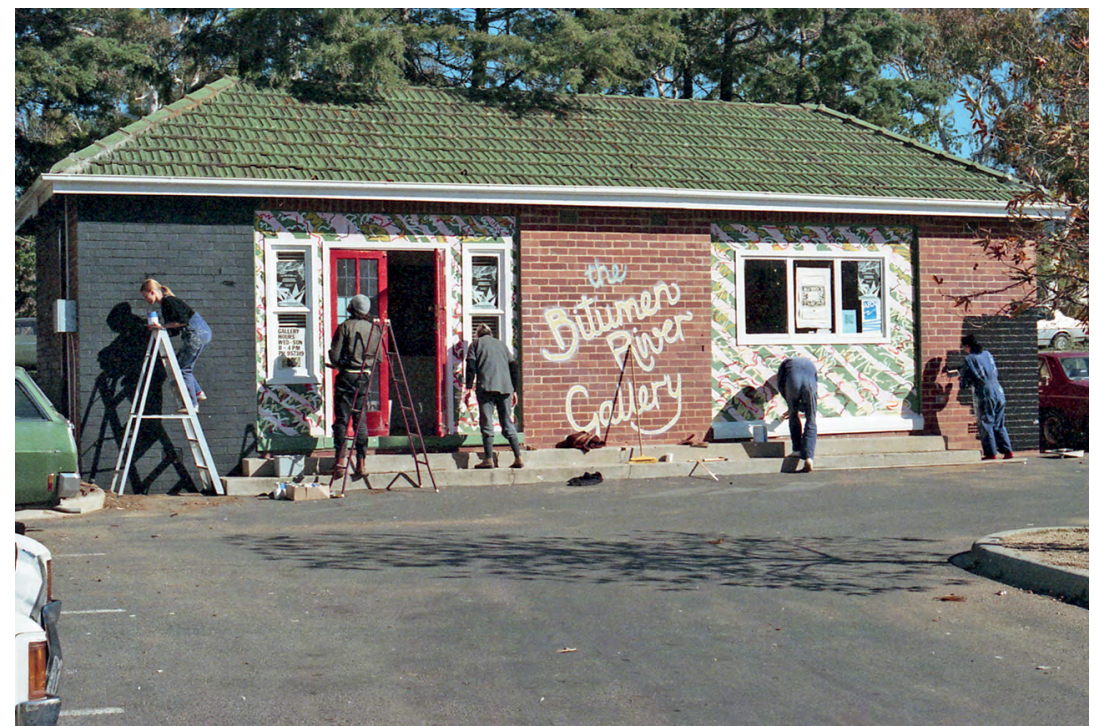

Figure 9. Collective members 'doing it for themselves', BRG Gallery

Source. CCAS image archive, reproduced with permission

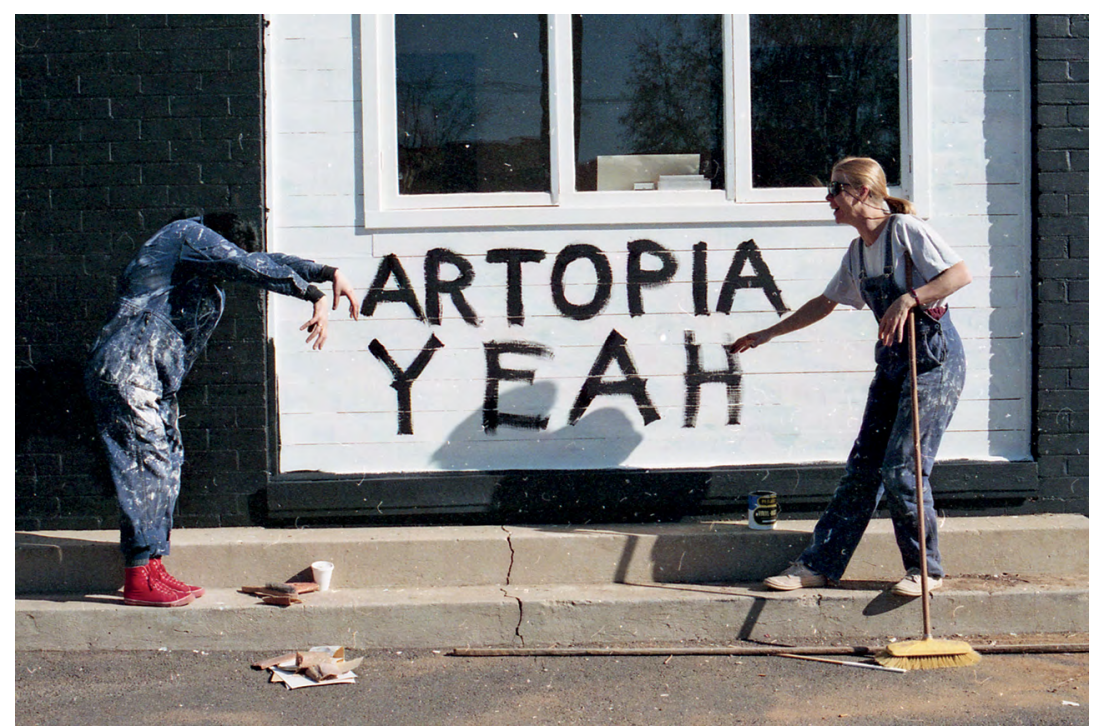

Figure 10. Collective members 'doing it for themselves', BRG Gallery

Source. CCAS image archive, reproduced with permission 


\section{Dreamtime machinetime}

Given the lack of experience and skills in gallery management, it is extraordinary that the second exhibition at BRG, Trevor Nickolls: from Dreamtime to machinetime was, albeit for very different reasons, as remarkable as the first. This exhibition opened at BRG a full three years before Koori art ' 84 introduced the work of contemporary city-based Aboriginal artists, previously known as 'Urban' artists, to Sydney. BRG's first exhibition centred it within national and international contemporary art discourses and its second exhibition anticipated a movement that has become one of the principal interests of art history since 1980: the transition of Indigenous art from ethnographica to contemporary visual art.

Nickolls, with dual Aboriginal/Irish heritage, graduated from the South Australian School of Art (SA SOA) (Dip Fine Art painting) in $1970 .{ }^{37}$ The trajectory of his work, which as a student was wholly concerned with Western/European subject matter and styles, gradually turned towards the dichotomy of customary Aboriginal life versus alienated urban living. By the late 1970s, he had met central Australian Warlpiri/Anmatyerre painter and senior lawman Dinny Nolan Tjampitjinpa, and began to incorporate dots and traditional Aboriginal mark-making in his works, developing his Dreamtime/machinetime thesis. ${ }^{38}$ In 1981 Nickolls arrived in Canberra as the HC Coombs Creative Arts Fellow at ANU. ${ }^{39}$

37 From the 1990s, Trevor Nickolls has been known as 'the father of urban Aboriginal art'.

38 Dinny Nolan Tjampitjinpa came from Yuendumu and moved to Papunya in 1972. He was one of the senior lawmen of the Warlpiri/Anmatyerre tribe who, with the support of teacher Geoffrey Bardon, began painting traditional designs on canvas, giving birth to the contemporary, grassroots (as opposed to the Urban Aboriginal art movement that would rise in the 1980s) Aboriginal art movement. Bardon characterised him as 'a wonderfully reliable man ... a gentleman. He was a determined painter for Papunya Tula Artists Pty Ltd and was a fine ambassador for the company during his visits to Melbourne and Sydney' (Geoffrey Bardon and James Bardon, Papunya: a place made after the story: the beginnings of the Western Desert Painting Movement, Melbourne, The Miegunyah Press, 2004, p 87).

39 Nickolls was determined to access family history and resources at the Australian Institute of Aboriginal and Torres Strait Islander Affairs (AIATSIS) but, unable to prove his Indigeneity at that time, he was denied access to the archives. 


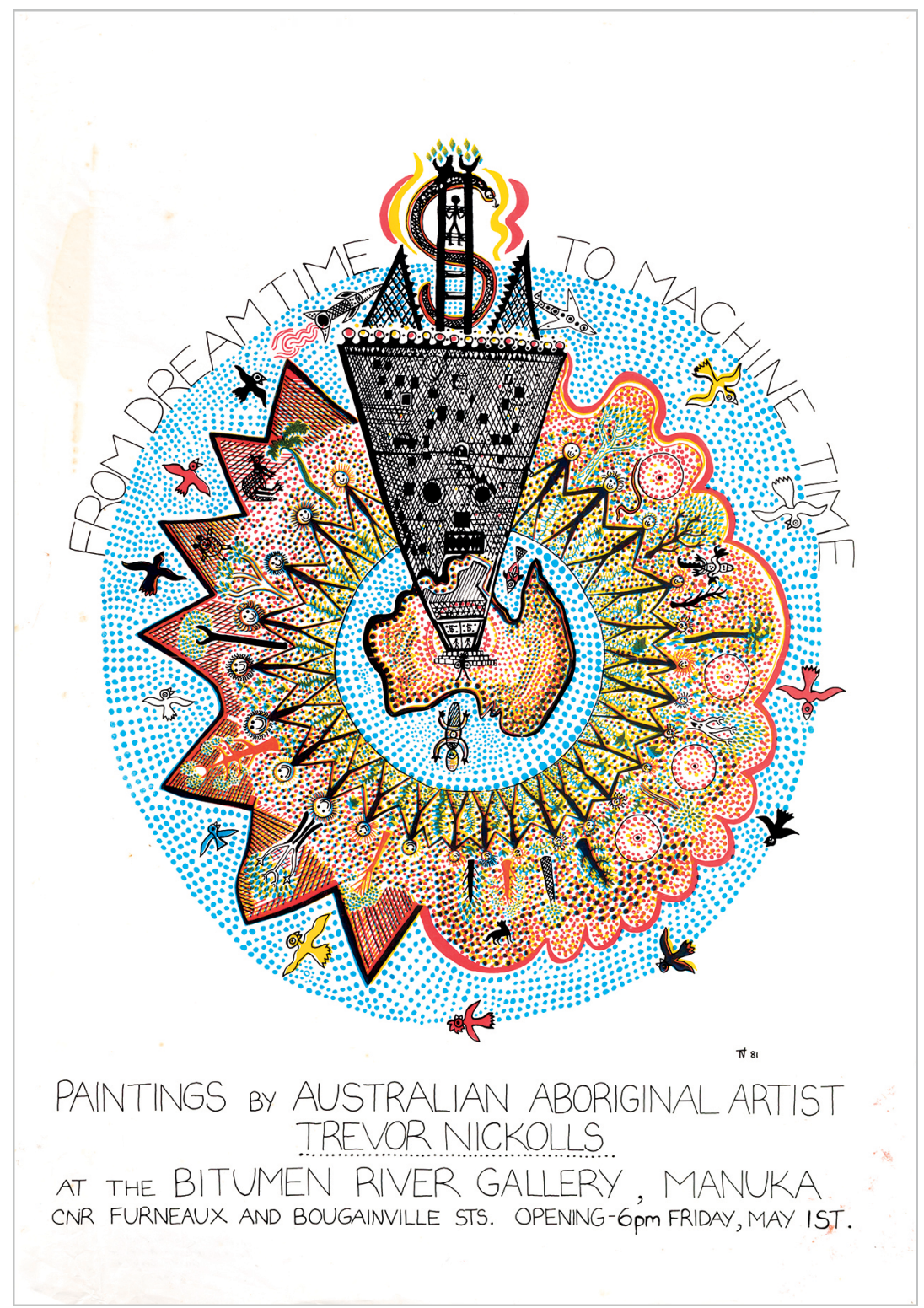

Figure 11. Alison Alder and Gaida Serilus, Trevor Nickolls, From Dreamtime to machinetime, exhibition poster, 1-17 May 1981

Source. Megalo archives, reproduced with permission 
The physical proximity of Australia's national university and the art school fostered important collaborative links between radical students from both institutions. Ford, still a student at CSA, met Nickolls on campus and together with Little - who had met Nickolls during his time as arts adviser for Tiwi Designs from 1976 to 1980 - suggested that Nickolls hold an exhibition at the about-to-be-opened BRG.

Serilus and Alder printed exhibition posters and the invitation (see Figure 11) and, afterwards, Nickolls gave Alder a drawing. She remembers his work as 'luminous. It sang out from those red brick walls' ${ }^{40}$

Nickolls exhibited 26 recent paintings at BRG. Comments in the visitors' book reflect an audience not yet literate in the language of contemporary Indigenous art, with responses ranging from 'Quite impressive (reminds me of Aboriginal work)' to 'Exciting, wonderful detail. Shows terrible dilemma of black culture - your women are so fierce!'41 ANU head of Art History and Canberra Times reviewer Sasha Grishin applied his considerable scholarship in writing the first review of Nickolls' art practice by an art historian, noting that Nickolls was 'consciously creating his own personal expressive language freely using ... a blend of forms drawn from traditionally Aboriginal arts and modern western conceptions of painting. ${ }^{42}$ While ultimately recognising Nickolls' work as 'coherent and potent', Grishin felt that 'in a number of his paintings, the imagery becomes too much an illustration of political ideas to work satisfactorily as a visual unity. ${ }^{43}$

It was precisely the 'illustration of political ideas' that heralded the soonto-explode phenomenon of contemporary Urban Aboriginal art. Grishin was not alone in failing to recognise Nickolls' exhibition as the beginning of what would become an internationally recognised art movement. Three years later, reviewers would misunderstand the work in the seminal Sydney exhibition Koori art ' 84 as 'simulated and derived' 44 and dismiss

40 Alder, 2010.

41 Comments attributed respectively to Andrew Bray and Caroline Blesing, BRG visitors' book, 1981-83, CCAS archives.

42 Sasha Grishin, 'Aborigines in role of blood sacrifice', Canberra Times, 12 May 1981, p 15.

43 With reference to Adam Geczy's Buried alive (2007): 'Geczy is keenly aware of what he terms the "impossibility” of politically activist art, particularly in Australia' (Sasha Grishin, quoted in Jacqueline Millner, 'Elusive exigencies: art and social change', in Conceptual beauty: perspectives on Australian contemporary art, Sydney, Artspace, 2010, p 134).

44 Terence Maloon, 'Such sweet plunder', Sydney Morning Herald, 15 September 1984, p 49. 
it as 'a passing fad'. ${ }^{45}$ Yet, only six years after Koori art '84, Nickolls and Rover Thomas were the first Aboriginal artists to represent Australia at the Venice Biennale. ${ }^{46}$ Nickolls was a heraldic messenger and his position as the second exhibitor at BRG presaged the gallery's position as a harbinger of contemporary trends. ${ }^{47}$

BRG quickly developed a following among Canberra's arts community. Alder recalls established artists such as Rosalie Gascoigne dropping in, as well as National Gallery director James Mollison, whose description of BRG as 'that little punk gallery' swiftly found its way into print ${ }^{48}$ when, in his Canberra Times review of Nickolls' From Dreamtime to machinetime, Grishin wrote, '[Nickolls's works] are showing at the newly opened Bitumen River Gallery, a small punk gallery located at the Manuka car park. ${ }^{49}$

It is possible that Mollison, who was a warmly supportive, frequent visitor to BRG, was misinterpreted. In comparison to the National Gallery, Bitumen River must have seemed like some 'punk' kid, flexing its puny muscles and cocking its nose at the establishment. In any case, the moniker stuck through the first year, although it seems probable that the original meaning, of what was most likely a throwaway line meant to highlight youth versus The Establishment, became confused with a contemporary social movement. ${ }^{50}$ By 1983, Ayres took exception to the descriptive phrase, writing that BRG:

is not a 'punk' gallery. It has none of the violent anarchy which typifies a punk visual style. None of the people who run it stick pins in themselves or make their hair stand up on end like used toothbrushes..$^{51}$

45 Quoted in Brenda Croft, 'A change is gonna come', Periphery, 40-41, 1999-2000, p 52.

46 Ian McLean, How Aborigines invented the idea of contemporary art: writings on Aboriginal

contemporary art, Brisbane, Institute of Modern Art and Sydney, Power Publications, 2011.

47 Nickolls' exhibition title shares a wonderful synergy with the name 'Bitumen River'.

48 Alder, 2010.

49 Grishin, 12 May 1981.

50 There was a vibrant punk scene in Canberra in the early 1980s.

51 Ayres, 1983, p 11. 
Mollison continued to visit often. On 15 May 1982, artist Geoff Shera, who was sitting in the gallery, wrote in the visitors' book:

visitors included students, diplomats, Welsh tourists and Canberran workers. The Director of the National Gallery came along to the Gallery. He remarked that the Gallery was 'a very lively one'. Mr Mollison said it was a 'crazy exhibition' with the pot-pourri of glass, leather shoe bespoking mixed media work $\&$ drawings. I asked him when the National Gallery was being opened and he said October 13 (or was 8th) [sic] this year. He asked me if I knew the 'Young Italians', 'who in particular' I asked. 'the young Italian painters', 'painting in Italy?' I asked. He said 'Yes, like Clemente' I said 'No, what do they paint like, what's their stuff like?' He laughed and said 'like this!' 52

This anecdote illustrates the perceived gulf that existed at that time in the minds of collective members between national and local cultural spheres; between art in the institutions and art as practised by the members of BRG. On one hand, Mollison showed keen interest in the progress of this new wave of young artists; they were an accurate reflection of the thrust of broader contemporary art practice. Additionally, although the youth of these artists and the emergence of poster making and photocopy as mediums for artistic expression precluded serious collecting by other Australian art institutions, Roger Butler recognised the importance of the prints and posters being produced by both local and national collectives. With the support of Mollison and with funds supplied by then chairman of the National Gallery council, Gordon Darling, he immediately began acquiring posters and screen prints made by collective members for the national collection. Despite this quiet support, the about-to-be-opened National Gallery, with its prominent position in the national capital representing the apogee of the institutional model, epitomised a paradigm that these artists felt excluded them and that they rejected. Their focus lay in turning this paradigm on its head.

5215 May 1982, BRG visitors' book, 1981-83. Shera's remarks are transcribed directly from the visitors' book. 


\section{CSA and BRG: the beginnings of a symbiotic relationship}

CSA and BRG - and BRG's successor CCAS - have been engaged in a symbiotic and often complex relationship since 1980. The relationship between seminal staff and students at CSA from the latter years of the 1970s to the early 1980s reveals CSA's influence on BRG founding members. CSA, and in particular the Printmaking Workshop under senior lecturer Schmeisser and inaugural tutor Martin, provided a unique environment that directly contributed to the genesis of BRG. In this workshop a small group of politically inclined students were stimulated, particularly by Martin, who proved to be a politically and artistically literate tutor. While I acknowledge that other factors were important, the environment at CSA was critical to the growth of nascent contemporary arts exhibitions in Canberra, as evidenced through BRG's activities.

German-born Udo Sellbach, the school's inaugural director, took up his appointment in a period that Michael Agostino termed 'the financial halcyon days' of tertiary education in Australia. ${ }^{53}$ Federal government support, which in the pre-self-government years liberally funded education in the Territory, enabled the implementation of Sellbach's Bauhausinspired vision. This involved setting up discrete workshops within CSA, one of which was printmaking, as well as the removal of previously accepted barriers between art and craft. ${ }^{54}$ Importantly for the future of the Printmaking Workshop at CSA, Sellbach was a master printmaker trained in the European tradition who was active in furthering printmaking in Australia. In 1960, Sellbach and his printmaker wife Karin 'played a leading role in setting up the printmaking department at the SA SOA'. ${ }^{55}$ In 1966, Sellbach, Ursula Hoff and Grahame King established the Print

53 Agostino, 2009, p 33.

54 The Bauhaus vision accepted other disciplines, such as craft, architecture and design, as art. Its architectural influence is seen in Canberra in several privately owned houses and in the 1962-built public housing of the Northbourne Housing Group - designed by Ancher, Mortlock and Murray for the National Capital Development Commission (NCDC) in 1959 - and the Bega and Allawah flats in Braddon designed by Richard Ure in 1954. The Northbourne Housing Group and Bega and Allawah flats were sold to developers from 2016 as part of the ACT government's public housing renewal program, with the money raised used to assist in funding the city's light rail network. These buildings, demolished during 2017, were 'Canberra's and probably Australia's first and only true example of the rationale of the Bauhaus principles used for public housing' (Martin Miles, 'Northbourne Housing Group', Canberra house: mid-century modernist architecture, www.canberrahouse.com.au/houses/ northbourne-housing.html, accessed 23 March 2015).

55 Agostino, 2009, p 26. 
Council of Australia in Melbourne. ${ }^{56}$ In the 20 years before his arrival in Canberra, Sellbach lectured in printmaking in Adelaide, Melbourne, Brisbane and Hobart (where he was head of the Tasmanian School of Art). Agostino reveals that the Hobart appointment was rife with 'political infighting' and thus Sellbach, like many artists who migrated to Canberra from other Australian capitals, hoped that his appointment to CSA would provide 'a fresh start'. ${ }^{57}$

Shortly after his arrival in Canberra he invited Schmeisser, who had trained in both Western and Eastern printmaking traditions in Germany and Kyoto, Japan, to set up a new printmaking workshop at CSA. At the same time, he approached Adelaide painter, printmaker and lecturer Robert Boynes to take up a position as head of the Painting Workshop. Boynes' partner, Martin, then a printmaker with an emerging national profile, had recently begun teaching at Salisbury TAFE. ${ }^{58}$ Agreeing to come to Canberra if she could secure a tertiary position, she applied for and was accepted as the Printmaking Workshop tutor at CSA. Schmeisser, Boynes and Martin took up their positions together at the beginning of the 1978 academic year. ${ }^{59}$

\section{Mandy Martin: background and impacts}

Martin had a profound influence from the late 1970s to the early 1980 s on the students at CSA who founded and progressed Megalo and BRG, and on the development of contemporary political art in Canberra particularly prints and posters. She was only 26 when she arrived at CSA, but she brought with her a sophisticated understanding of the nexus of art and politics. Her early political and artistic development was framed by South Australia's volatile political environment, and enacted through her involvement with the Progressive Art Movement (PAM) and women at the SA SOA, and the various left-wing political parties engaged in battles

56 'The Print Council of Australia (PCA) was established in 1966 to encourage the production and appreciation of hand-printed graphics. The intention of the PCA was to stimulate printmaking activities, to encourage understanding and appreciation of the original print and to define the various types of printmaking (wood-cut, etching, engraving, lithograph or serigraph)' (MS 49, Papers of the Print Council of Australia, Australian Prints and Printmaking Collection, NGA Research Library, nga.gov.au/Research/pdf/MS49_FindingAid.pdf, accessed 21 April 2012).

57 Agostino, 2009, p 27.

58 Martin's work was included in Australian perspecta in 1981 and again in 1983; she had the first of many solo shows at Roslyn Oxley 9 Gallery in 1983. Interest in her work grew nationally and internationally between 1977 and 1983.

59 Agostino (2009, p 29) incorrectly states Martin and Schmeisser as commencing at CSA in 1979. 
in the SA car factories. Her political focus and her screen-printing skills, which she used on the ground in dangerous, real-life situations, directly influenced students who went on to establish Megalo and BRG, and therefore I make a close reading of her own influencing milieu.

At the beginning of 1972, Martin won one of five scholarships to the prestigious SA SOA. The early trajectory of Martin's career was set by three factors that, in turn, awakened her political conscience, gave her permission to make art outside of the academic paradigm, and furnished her with the skills to do so. The first, in the second semester of her first year, was the arrival from England of Clifford Frith as lecturer in Foundation Studies. Frith's novel approach to teaching - 'Why teach anything, why not do crochet classes?' - legitimised the making of art outside entrenched academic boundaries. Martin recalled, 'I headed to the Adelaide Hills and built a geodesic dome which was an "investigation of an interior space" ... I never painted again at art school'. ${ }^{60}$ The second, in 1973, was her decision to take Brian Medlin's course 'Politics and art' at Flinders University, which she found intellectually and politically stimulating as it explored the international intersections of art and politics. The third factor was her decision, in 1973, to seek out Boynes, who taught her to photo-screen print. This skill, which she passed on to her long-term collaborator Annie Newmarch, gave the two women an entrée into the highly politicised world of SA car manufacturing.

Under reforming Labor Premier Donald 'Don' Dunstan, South Australia styled itself as the 'State of the arts' and was arguably the most politically volatile of the Australian states and territories in the 1970s. Its industry was dominated by American car manufacturers Chrysler and General Motors Holden, which were the state's major employers and where the factory floors had, since the 1960s, become sites of escalating worker/ management conflict. The complex industrial relations scenario was compounded by the number and diversity of small, left-wing political groups that were pitted against the companies, the state government, the industry's major union the Vehicle Builders Union (VBU) and, often, against themselves. Among the factions with a presence on the shop and

60 Mandy Martin, 'The South Australian School of Art at Stanley Street North Adelaide 1972-5', University of South Australia, School of Art, Architecture and Design, w3.unisa.edu.au/ artarchitecturedesign/about/mandymartin.asp, accessed 17 April 2012, site discontinued. 
factory floors were groups including the Communist Party of Australia Marxist Leninist (CPAML). ${ }^{61}$ The CPAML played a pivotal role, firstly in Martin's political awakening and then in her disenchantment with the nexus of art and politics as evidenced in South Australia.

Martin became an early and active member of PAM. Centred around Flinders University, PAM was formed by a group of artists, performers, musicians, filmmakers and writers in 1974. This tendency towards cross-art form fertilisation was echoed in the Clifton Hill Community Music Centre in Melbourne and in Canberra's own fluid, homogenised subculture of artists, musicians and performers from the late 1970s. PAM comprised a like-minded group who had:

turned their backs on conventional art modes and favoured massmedia forms of communication like video, photography and screenprinting rather than painting which we saw as an elitist and anachronistic activity. ${ }^{62}$

PAM quickly became a front organisation for WSA and for the secretive CPAML.

Martin's emerging political focus and photo-screen printing skills found their logical outlet in the Adelaide factories and workplaces of the American car manufacturers. The strategies employed by the CPAML on the factory floor followed the model of the Maoist two-stage revolution in working with the capitalists to expel the foreign imperialists - in this case, the American car manufacturer - and supporting the working-class struggle. The CPAML made effective use of cultural and arts workers, including Martin and Newmarch, to make rapid incursions onto the factory and shop floors with union-backed sloganeering that took the form of the immediately produced and disseminated screen-printed poster. In 1989 Martin recalled that:

61 Other groups included: the Communist Party of Australia (CPA); the Socialist Party of Australia; the Worker Student Alliance for Australian Independence (WSA); the Socialist Workers Party (SWP); the Socialist Labour League (SLL); the International Socialists (IS); and the Rank and File group (RAF), which was often accused of being a front for the WSA. List sourced from Garry Hill, 'Anatomy of an industrial struggle: Chrysler factory at Tonsley Park in Adelaide 1976-1978' (Radical tradition: an Australian history page, www.takver.com/history/chrysler.htm, accessed 18 April 2012).

62 Mandy Martin, 'Political posters in Adelaide', conference paper, Australian Print symposium, National Gallery of Australia, Canberra, 1989, www.printsandprintmaking.gov.au/references/409/, accessed 10 April 2012. 
Cultural workers had moved into the car factories and onto the rank and file of organisations in the car factories, and artists like Annie and I were right in behind, setting up exhibitions and demonstrations in the factories and workplaces. We screenprinted posters and stickers on the spot and images like When workers unite, bosses tremble and other plagiarised symbols from May 1968 in Paris, which enraged management as [posters and stickers] appeared minutes later on machinery and doors around the factories. ${ }^{63}$

Politics, both through the CPAML and via a growing interest in feminism, dominated this stage of Martin's life. She was printing political posters by day (at one stage she was banned from using SA SOA Printing Workshop inks and from using the workshop itself during school hours) and attending political meetings at night. As vice-president of the Student Representative Council (SRC), Martin 'donated the entire funds of the SRC, a whole $\$ 240$, to the PLO'64 and 'turned the office into a crèche for students with babies'. ${ }^{65}$ Importantly, together with a group of women art school students, she founded what was arguably the first women's art group in an Australian art school. This energetic involvement with feminist politics, which Martin had viewed as contiguous to her leftist political endeavours, was in fact highly unwelcome within the CPAML cadre. Under the Maoist two-stage revolution concept, the women's revolution (along with gay rights) came in well behind the workers' revolution. Martin recalled: 'Even doing posters for things like the women's shelter was frowned on because the feminist, women's movement was considered a waste of energy. ${ }^{66}$

This perceived incompatibility of her twin political interests was thrown into sharp focus by events that followed a visit by American feminist Lucy Lippard and Australian art critic Terry Smith. Lippard, visiting Adelaide as part of a lecture tour and to source images for the first issue of the American Feminist publication Heresies, stayed with Martin and Newmarch. In town at the same time was Smith, who had spent 1972-75 in New York, where he studied at The New York Institute of Fine Arts and Columbia University and joined the conceptual artists' group Art \&

63 Martin, 1989.

64 Palestine Liberation Organization.

65 Mandy Martin, 'South Australian School of Art'.

66 Mandy Martin, interview with the author, 4 April 2012. 
Language. The CPAML considered the two to be 'lackeys of American Imperialism' ${ }^{67}$ Lippard was a powerful advocate for feminist artists, and both she and Smith were working at the cutting edge of contemporary American arts criticism. Martin was 'pulled in for a whole day of disciplining by the cadre of the CPAML for fraternising with the enemy' ${ }^{68}$

This experience led Martin to realise that membership of PAM, and by default the CPAML, curtailed her freedom of artistic thought and political will equally as restrictively as the academic art school paradigm. Allied to this sense of a loss of creative and political autonomy were her concerns over increasing violence at Chrysler's Tonsley Park factory in the lead-up to the riots and mass sackings of June/July 1977. Martin viewed the internecine factional wars as 'callous and interfering in working class peoples' lives. People [were] being beaten up by the police, going to jail, losing their jobs when they had families to support'. ${ }^{69}$

In the Australian car industry's history of significant unrest, the period of Martin's involvement as an active member of PAM is arguably the most bitter. Its intensity meant that Martin experienced an extreme introduction to the politics inherent in the trade union nexus of worker/unions/owners/ political factions, and to art as a means of political activism at the coalface. The divisions and self-serving nature of much of the struggle, and the particularly bloody events leading up to and surrounding the July 1977 vote for increased workers' rights, signalled the end for Martin: 'I didn't want to hit people over the head any more, and I wanted to be able to critique both capitalism and socialism. ${ }^{170}$

In other words, Martin required freedom to respond to the world as an artist, anticipating and reflecting change as her interests dictated, free of any imposed ideology. The time was ripe for the move to Canberra:

67 This phrase referred to anyone who sympathised with American concerns or worked within American cultural spheres.

68 Martin, 2012.

69 Martin, 2012.

70 Martin, 1989. 
By the time I left Adelaide I was pretty pissed off. I was looking for something that wasn't partisan, that was actually about fostering artistic practice and emerging artists, because I knew, as a fairly young artist myself, how difficult it was to bang your head against establishment walls. It still is, but it was particularly hard then. ${ }^{71}$

Martin and Boynes arrived in a Canberra that was 'a breath of fresh air', a sentiment that echoed Sellbach's feelings about his move to Canberra representing 'a fresh start'. ${ }^{72}$ Martin's national reputation was on the rise and she was actively seeking a bipartisan and open forum within which to operate. ${ }^{73}$ In 2012, she recalled that the move to Canberra signified:

a clean slate because although people like Humphrey McQueen ${ }^{74}$ for example had preconceptions about who Robert and I might be, in fact it was tremendously liberating to get over here and be able to paint without being criticised about not making political art. I'd come from a pretty tough ideological environment where every colour and every word and so on was analysed. If it wasn't approved by the rank and file of Chrysler and GMH [General Motors Holden] then you weren't allowed to do it. So yes it was really liberating coming to Canberra where you could reinvent the wheel a little bit. ${ }^{75}$

Martin's Adelaide experiences had a significant effect on the students under her tutelage in the Printmaking Workshop. When tasked with setting up the workshop, she first pasted the walls, floor to ceiling, with political posters, demonstrating her experience of photo-screen printing in a live political context. Additionally, her knowledge of and connection to the feminist and women's art movements and her relative youth provided a real alternative to Schmeisser's more traditional and technically rigorous approach to printmaking and teaching.

71 Martin, 2012. Although this intense period of art-making from within a political collective and for the collective cause was over, Martin has continued to paint works that reflect on the plight of the worker and the degradation of the environment by corporations.

72 Quotes respectively: Martin, 1989; and, Agostino, 2009, p 27.

73 Grishin reviewed Martin's drawings in the CSA staff exhibition of May 1979 as 'increasingly more powerful and intense' ('Diverse exhibition united by standard of excellence', Canberra Times, 15 May 1979, p 15).

74 McQueen resigned from CSA on 1 February 1979 to take up a two-year Australia Council Literature Board Fellowship. He returned to Canberra in time to open BRG in April 1981.

75 Martin, 2012. 
Martin's appointment constituted the first full-time appointment of a female at the art school for six years. ${ }^{76}$ She was at least a decade younger than any of her male colleagues and, therefore, closer in age to many of her students. Included in the first undergraduate intake of 1978 were Alder, Ford, Ayres, Morrow, Denton, Cassie Moulen, Nick Cosgrove and Di Wells. Church entered Photo Media in 1979 and, in the same year, Kath Walters enrolled in the Print Workshop. ${ }^{77}$ Having completed a semester of Foundation Studies (later Core Studies), these radicalised, hippie-leaning, feminist, activist students, aged in their early 20s, were hungry and open to the idea of art as a socially useful vehicle. Martin was ideally suited to inspire and support their particular social agenda. ${ }^{78}$

With such vastly different backgrounds and trajectories of learning and teaching, it was inevitable that Schmeisser and Martin soon found themselves at odds, particularly with the concept of the value of the alternative within the student body and with the academic values placed on various students' work. As Martin noted: 'Jorg couldn't get it. He didn't understand my anti-establishmentness or that within rebellion and difference you could find immense creativity. ${ }^{79}$ Martin recognised the importance of the work being produced by students such as Denton, Moulen, Alder, Church, Ford and Ayres, and was determined to support and nurture their talents. 'I argued about the assessment of nearly every one of those students who was special to me'; it was 'a battle the whole time I was in printmaking ... assessment was difficult; it needed a sympathetic outside examiner to understand the feminist, gay, Asian, student body'. In the end, Schmeisser and Martin 'came to a truce' and, with the support of students, essentially divided up the classes; the radicalised group of hippie firebrands came under the exclusive mentorship of Martin. ${ }^{80}$

76 Since Gillian Mann in 1972 (who, in addition to other contributions to the arts in Canberra, developed the printmaking curriculum for CSA) and Pat Harry, also in 1972, in painting.

77 Church remembers Walters as 'really the key person ... [she] taught me screen-printing and she later became my partner in crime in Melbourne' (Church, 2012).

78 Martin's late-night experiences in the print room of the SA SOA were mirrored by the early 1980 s cohort in Canberra. Printmakers whose work responded more to contemporary social concerns than to art orthodoxy were generally less inclined to play by the rules. Church recalled, 'I think the best times I had at the art school were when I used to break in at night and screen-print ... doing experiments ... printing on plastic and that was really lovely' (Church, 2012).

79 Martin, 2012.

80 Martin, 2012. 
This informal arrangement didn't close the workshop to any student. There are many students from that time, including Canberra printmakers Julie Bradley, Dianne Fogwell and Ben Taylor, whose long careers benefited enormously from Schmeisser's rigorous training. Nor was Martin's tutelage any less rigorous. But it is arguably true that the energetic and understanding support extended by Martin impacted positively on the group of students who went on to form Megalo and BRG. ${ }^{81}$

This support was not limited to in-school experiences. Martin provided additional opportunities for her students to make art outside art school that encouraged the rise of the underground printmaking culture whose apogee was the establishment of Megalo by Alder and her fellow printmakers in 1980. Martin had shipped her Adelaide print studio to her new home in Queanbeyan and it became a focal point for that first group of students. She recalls that:

In the second part of that first year when I went into printmaking [that group of students] all sort of became [friends]. They'd come out and do a bit of printing there because I had a full studio I'd brought over from Adelaide, racks and one arm bandit and dark room [which] I'd set up in Queanbeyan in the double garage. ${ }^{82}$

Later in that year, a pregnant Martin and Boynes moved their household from Queanbeyan to Canberra. Martin recalls the moving of her own print workshop to Gorman House:
Alison and Paul and Mark and Julia and so on helped me move and [in 1982] we set up ACME Ink at Gorman House. ${ }^{83}$ We rented those 4 little rooms there - one was the layout room, one was the office, one was the printing room and the other was the dark room. I'd pay the rent and, in exchange for helping print my work, they'd use the facilities. I didn't do a lot of printing at that stage - a couple of editions a year - and they'd print that work for me. So it was at that stage that we did things like True Bird Grit. ${ }^{84}$

\footnotetext{
81 By April 1981, Alder and her core group had set up BRG. Martin saw the gallery as an important way of developing the emerging artists - I did participate in a few shows there but it wasn't fundamental to my survival. I mean there was nothing here when we first came. Abraxas Gallery had just folded and the National Gallery wasn't open. There was just so little happening so it was great to have somewhere that became a focus' (Martin, 2012).

82 Martin, 2012.

83 For which Roger Butler did the plumbing!

84 Martin, 2012.
} 


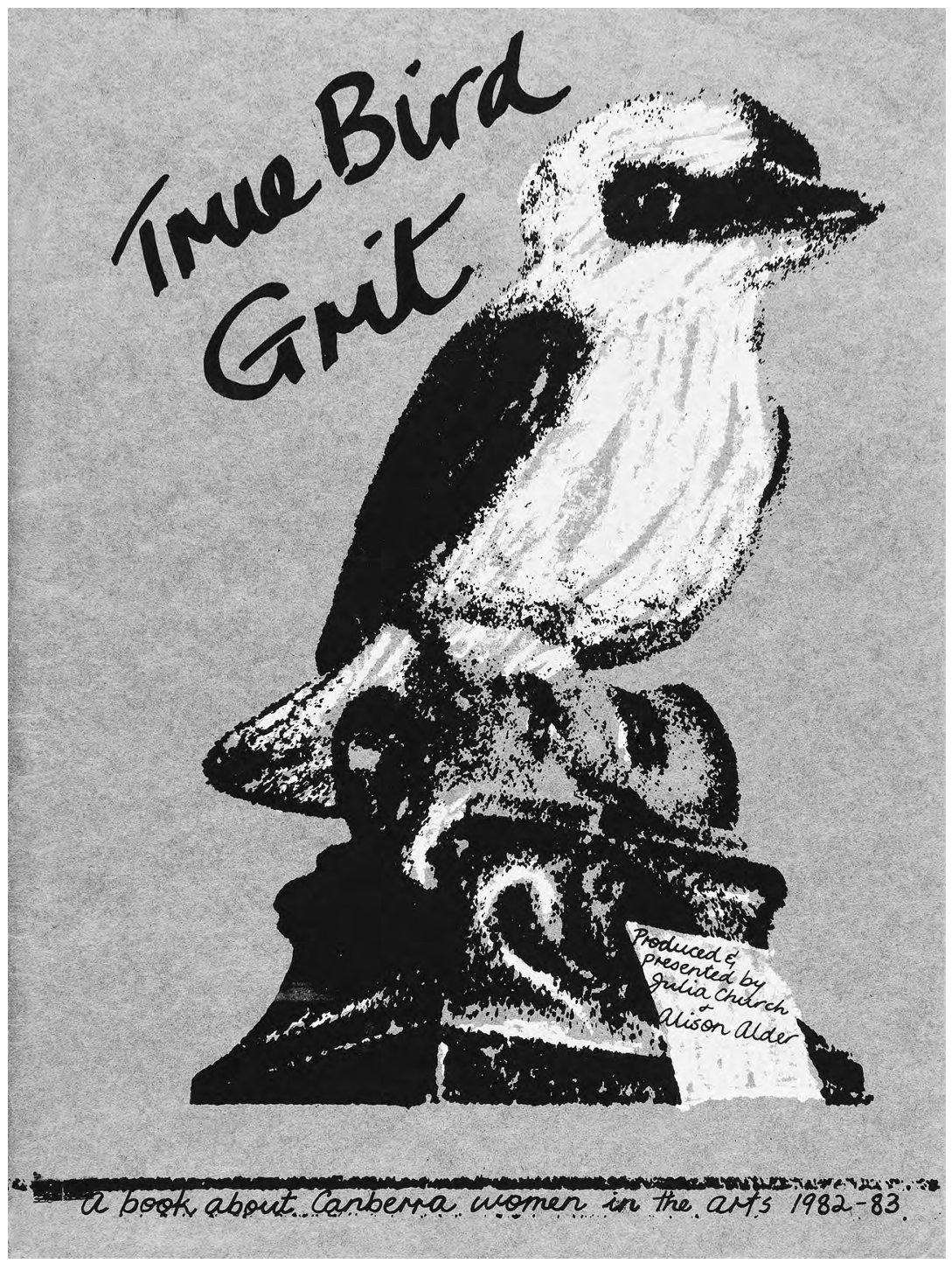

Figure 12. Alison Alder and Julia Church, True bird grit, book cover

Source. Photographer: Rob Little, reprinted with permission 
Alder and Church printed True bird grit in 1982 at ACME Ink, and its production pulled together a diverse group of women working in multiple cross-art forms throughout Canberra. Martin remembers it as 'quite a funny document, really, and it was in response to looking at Canberra and thinking, "Well, where are the women artists?" 85 Having already experienced the social and artistically nurturing value of a women's art group in Adelaide, Martin looked for evidence of a women's art movement when she first arrived in Canberra and established that there wasn't one:

but there were a couple of women who were interested. There was Barbara Campbell the American feminist artist, who'd been friends with people like Nancy Spero and Lucy Lippard and she'd come straight from that [milieu] to Canberra. Also Karilyn Brown ${ }^{86}$ came to Canberra around that time. ${ }^{87}$

Martin's contribution to the development of contemporary art in the region extended beyond the teaching experiences enjoyed by consecutive years of students during the period from 1978 until 2002, when, although she remained at CSA, she left the workshop. ${ }^{88}$ Her sociopolitical conscience and knowledge and her involvement with current political thought were powerful motivating factors in the development of the political stance of that first group of students who went on to form Megalo and BRG. Her strong leadership likewise enabled enduring friendships between students, linked as they were by common ideas and burgeoning political awareness. Later, many of those who returned to or arrived in Canberra to teach at CSA, such as Toni Robertson and Nigel Lendon, applied for their roles with Martin's encouragement.

85 Martin, 2012.

86 Towards the end of 1982, Brown acted as temporary coordinator of BRG and was instrumental in mobilising the nationwide campaign for free admission to the National Gallery (see Chapter 2).

87 Martin, 2012.

88 Martin left the workshop in 2002 (although not the CSA) over increasing health and safety concerns regarding the effects of printing chemicals. The school later converted the workshop to use water-based inks (Agostino, 2009, p 26). 


\section{Ingo Kleinert and 3 Acts}

It is timely at this point to highlight the tremendous contribution made by the CSA's Ingo Kleinert, who took early steps to illuminate the national contemporary scene for students, directing a series of three performance art festivals ACT 1 (1978), ACT 2 (1980), and ACT 3 (1982). ${ }^{89}$

Kleinert (b 1941) migrated to Australia from Germany in 1949 and studied art at Caulfield Technical College and Melbourne Teachers' College. Dividing his time between Europe and Australia from the late 1960s to 1975 , in June 1976 he was appointed to the Visual Communication Workshop in the newly independent CSA and he arrived in Canberra, from Adelaide, at the beginning of 1977.

The artists who coalesced around Adelaide's Experimental Art Foundation (EAF), which was established by Donald Brook in 1974, were working at the forefront of performance and experimental art in Australia in the last half of the 1970s. Kleinert's strong philosophical connections to Adelaide's experimental art scene were exemplified in ACT 1: recent and experimental Australian art in which half of the 22 artists were from the city, including Noel Sheridan, inaugural president of the EAF. ${ }^{90}$

A modest grant of $\$ 2,500$ from the Australia Council and the ACT division of the Arts Council, plus a $\$ 1,000$ in-kind administrative budget from the latter, supported the one-week festival. The majority of performances were held in the incomplete arts centre at ANU, 'a mass of brick spaces of varying sizes'. ${ }^{91}$

Joan Kerr, in one of the first Canberra art reviews in a national arts magazine, favourably reviewed ACT 1 for Art and Australia, writing that 'national participation made [a] sense of common purpose comprehensible and gave greater strength to the individual works. For both participants and viewers it seemed an experience worth building on'. ${ }^{22}$

89 ACT 1: 4-17 November 1978, included 22 artists and a budget of \$3,500; ACT 2: 18-20 April 1980, 41 artists, 60 performances, budget $\$ 8,000$ (\$4,000 from the Visual Arts Board (VAB), $\$ 2,000$ from the Department of the Capital Territory (DCT), and $\$ 2,000$ ( $\$ 1,000$ in kind) from the Arts Council (ACT division)); ACT 3, 8-10 October 1982, 10 invited artists, VAB funded. Kleinert's wife, Sylvia Kleinert, assisted him, as did workshop lecturer John Reid, from ACT 2 on.

90 Artists included: Jim Cowley, John Davis, John Fisher, Marr Grounds, Ian Hamilton, Leigh Hobba, Liz Honybun, David Kerr, Richard and Pat Larter, Kevin Mortensen, John Nixon, Jillian Orr, Mike Parr, Bob Ramsay, Lesley Savage, Noel Sheridan, Terry Smith, Richard Tipping, Tony Twigg, Ken Unsworth, Donald Walters, Arthur Wicks.

91 Joan Kerr, 'Act 1', Art \& Australia, 16, 4, 1979, p 320.

92 Kerr, 1979, p 321. 
The catalogue for ACT 1 documents a pivotal moment in performance art in Australia. Internationally and at home, performance art had been circling the margins of contemporary art practice from the early 1970s. This was made explicit in the catalogue's title page, which defined works as 'innovative by operating on grounds not previously tested by time and general public acceptance. ${ }^{93}$ The catalogue documented the festival's performances and also included a trail of letters from artists, artist callouts, support requests, responses from the Arts Council (ACT) and two essays on contemporary performance arts practice from Terry Smith and Paul McGillick.

The 1978 festival occurred two years before Canberra's poster and print makers came together under Megalo International Screenprint Collective and three years before the establishment of BRG. While it's difficult to quantify the effects that these three festivals had on emerging local contemporary arts practitioners, Kerr, alert to the creative power of visual memory, wrote of $A C T 1$ that 'what stayed in the mind after the festival had ended was a series of images..$^{94}$ Importantly, generous institutional support was on display; the support of the art school by ANU played out in the provision of spaces; the National Gallery's Daniel Thomas chaired an open panel, and Mollison extended moral and practical support; and the CSA, under Sellbach, gave unqualified support to Kleinert's endeavour. The exposure to national practitioners; the growing links between Adelaide and Canberra, which continued through the 1970s and 1980s with the arrival of Martin, Boynes, and other Adelaide artists; the fertile tensions emanating from national capital politics; and the exposure to incipient art forms, all contributed to a climate of possibility and open-ended practice.

This institutional support continued to play out through the late 1970s and early 1980s; however, other requirements for the flourishing of a contemporary arts practice were yet to evolve, and appropriate exhibition spaces and arts sector development funds were in short supply. In 1982, as ACT 3 coincided with the opening of the National Gallery, Kleinert retired from festival production in order to concentrate on an increased teaching load and his own creative work. By then, performance

93 Act 1: an exhibition of performance and participatory art, exhibition catalogue, np.

94 Kerr, 1979, p 320. 
art was being incorporated into the lexicon of contemporary practice internationally and nationally, and both Megalo and BRG had been established in the nation's capital. ${ }^{95}$

The BRG collective, through the making and exhibition of posters, was committed to local, national and international artistic political expression. Many of the issues expressed in the work of its members were indivisibly yoked to feminism. BRG artists were developing their local practice within the national capital at the heart of federal politics, but were mentored by older women artists with lived experiences of using art as a political tool, and were beneficiaries of the many advances for local women achieved since 1970 by CWL's second-wave feminist activism. It is fair to conclude that, by 1983, these young artists were exceptionally politically aware. How, then, to explain the rejection of a feminist poster titled Slut, made by Melbourne artist Catriona Holyoake in 1983 and heralding feminism's approaching third wave, that was offered to the BRG collective for sale? This fascinating and subtle conundrum, in which highly politically aware artists showed themselves to be out of touch with the earliest expressions of third-wave feminism that were burgeoning in Melbourne and other major centres, indicates that emerging changes in feminist theories and representations took hold differently in Canberra. ${ }^{96}$

95 As well as the aforementioned articles and catalogue, for more on these three festivals see: Anne Sanders, 'ACT 1, 2 \& 3: Canberra's national performance art festivals' (Art Monthly Australia, 259, 2013, pp 51-54) and, Ingo Kleinert, 'Act 2: for the record' (Art Network, 2, 1980, p 45).

96 First-wave feminism arose during the nineteenth century and continued into the early twentieth century. Its primary concerns - evidenced through the suffrage movements in the United States, the United Kingdom, Australia and New Zealand - centred around political equality for women, including the right to vote, the right to stand as candidates in elections, and rights around marriage and children. From 1949, a Marxist critique of capitalism as a root cause of women's inequality entered the discourse and remained a driving factor throughout second-wave feminism. Second-wave feminism arose in the United States from the early 1960s. It built on the political gains of first-wave feminism in that it sought to identify and remove cultural inequalities that the feminist movement recognised as barriers to full political equality. It was intrinsically linked with the women's liberation movement and it used crossnational consciousness-raising meetings to proselytise its aims. These disavowed all forms of patriarchy, including the uneven representation of women artists in museums and art galleries and issues around equality of career choice, remuneration and working conditions and physical and sexual safety for women and children. The concerns of third-wave feminism, made visible in posters from the early 1980s, arose as a sociopolitical movement during the early 1990s in the United States and co-exists to the present day with second-wave feminism. It is seen as a somewhat reactive movement to second-wave feminism's insistence on equalising sexual difference between men and women and it seeks to reclaim and celebrate women's differing sexuality. It includes a diversity of theories and a fluid approach to gender (see Cathia Jenainati and Judy Groves (eds), Introducing feminism (London, Icon Books, 2010); Rozsika Parker and Griselda Pollock, Framing feminism: art and the women's movement, 1970-1985 (Kitchener, Canada, Pandora Press, 1987); Laura Meyer with Faith Wilding, 'Collaboration and conflict in the Fresno Feminist Art Program: an experiment in feminist pedagogy’ (N.paradoxa, July 2010, vol 26)). 
A close reading of the circumstances in Canberra and in Melbourne surrounding the rejection of Slut considers these emerging differences between second- and third-wave feminist representations of women. Further explaining why these young artists were so preoccupied with feminist concerns, are the following stories of the contrasting journeys to Canberra of Australia's foremost feminist artist Vivienne Binns and early BRG member Cherylynn Holmes. Their journeys and impacts, different again to that of Martin's, contextualise the various factors within the women's movement that marked this period of contemporary art development in Canberra.

\section{Feminist politics and art: intersections}

The young male and female students and activists who founded BRG were diverse but interconnected people engaged in various cultural and social justice organisations and collectives; as such, they could not help but be radically politicised. Activists were visible within a relatively small Canberra population that grew from around 140,000 in 1970 to around 235,000 by 1983 . Additionally, they were agitating at the heart of political and judicial decision-making in Australia, which drew feminist activists from around the country at various times and increased both the sense of urgency and the perceived effectiveness of political actions. ${ }^{97}$ BRG founders and early supporters, largely born around 1960, were beneficiaries of the gains won by second-wave feminists who had been active internationally, including in the United States from the late 1960s and in Australia since 1970. The ACT chapter of the Women's Liberation Movement, CWL, was formed in June 1970. Founding member Ward remembered that, in March/April 1970, she invited Sydney feminist Lyndall Ryan to Canberra:

97 For example, International Women's Day was revived on 8 March 1972. In 1973 women from around Australia set up a Tent Embassy outside Parliament House for three months in the lead up to and during the Lamb-McKenzie Private Members Anti-abortion Bill. In 1973, Ward, Haley, Daphne Gollan and Susan Magarey from CWL organised a national conference on feminist theory at Mt Beauty in Victoria (the 'Theory' very much tongue in cheek). International Women's Year in 1975 brought two conferences to Canberra: the Women and politics national conference, organised by Elizabeth Reid (who was appointed Whitlam's women's adviser in 1973), was held at ANU and the Anarchist feminist conference (again, organised by CWL). Some of the women who were instrumental in CWL and Women's Electoral Lobby (ACT) were Carol Ambrus, Sara Dowse, Gollan, Haley, Beryl Henderson, Magarey, Drusilla Modjeska, Gail Radford, Reid, Julia Ryan and Ward. 
She said 'Yes' and she and Coonie Sandford - an Australian woman who had been living in the US and later went back there - came here and spoke to us on a Saturday afternoon. The women there that day agreed to meet on Wednesday night and met every week for six years. ${ }^{98}$

Between 1970 and 1980, Australian women gained significant ground in the battle for equality on many fronts, with escalating gains made between 1972 and 1975 as a result of the swift implementation of useful legislation and funding by the Labor government under Gough Whitlam. In Canberra, the highly effective Women's Electoral Lobby (WEL) ACT (established 1972) made successful submissions to government that had far-reaching consequences. In the same year the Aboriginal Tent Embassy was founded and became a nationally recognised space for Indigenous political lobbying. WEL ACT and CWL supported Pat Eaton, the first Indigenous candidate, to stand (unsuccessfully) for federal parliament in 1972 as an independent candidate on women's and children's issues. In Canberra, women's services that received some level of government funding as a result of local lobbying included the Canberra Women's Refuge in 1975, followed in 1976 by the Rape Crisis Centre. ${ }^{99}$ BRG opened in April 1981, in the same month in which women commemorating the rape of women in war first marched in Canberra's Anzac Day Parade and were arrested for doing so. Arguably, Canberra, from 1972, could be seen as operating at the cutting edge of political feminism in Australia. ${ }^{100}$

98 Biff Ward, email to the author, 11 July 2016.

99 Elsie House, Sydney's Women's Refuge, opened in Sydney in 1974. The Canberra Women's Refuge was opened on International Women's Day, 8 March 1975.

100 'Over its history as the national capital Canberra has witnessed a distinctive phenomenon: the capacity of activist women - many of them also public servants - to work within governmental structures to achieve broad-ranging improvements to the lives of women and families in Canberra and across Australia' (Roslyn Russell, 'Activists', From Lady Denman to Katy Gallagher: a century of women's contributions to Canberra, 21 February 2013, www.womenaustralia.info/exhib/ldkg/activists.html, accessed 15 August 2014). 


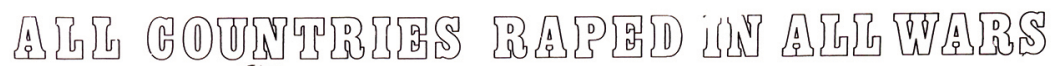

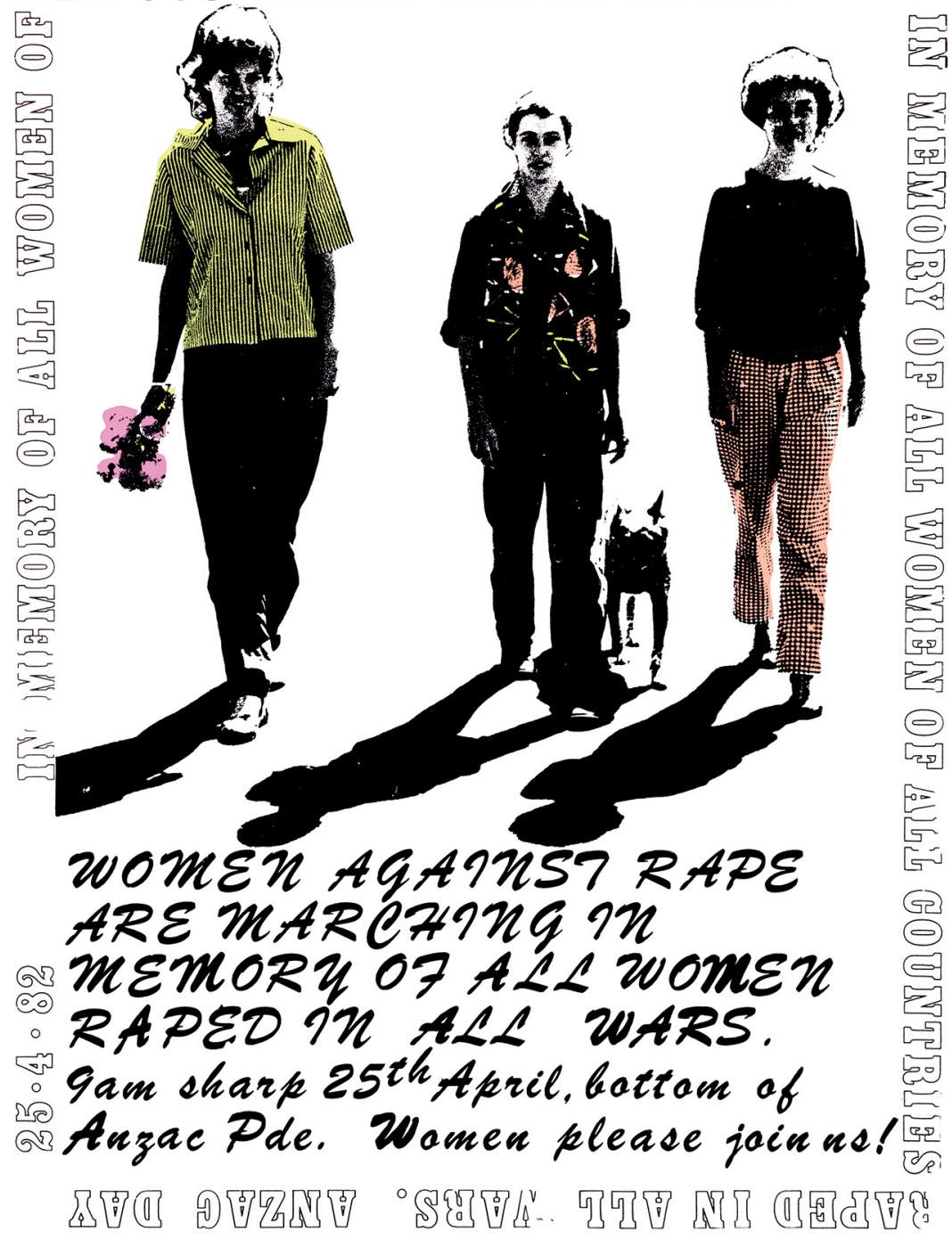

Figure 13. Women against rape march, poster, April 1982

Source. Printed by Megalo, Megalo poster archive, reprinted with permission 


\section{Cherylynn Holmes and the utopian ideal}

In the late 1960s in Australia, the utopian ideal found political expression through the work of Jim Cairns, Labor Member for Yarra (1955-69) and Lalor (1969-77), and, briefly, deputy prime minister in the Whitlam government. He drove a relentless course for change, firstly as a spearhead of the anti-Vietnam protest movement and then as a leader of the countercultural movement. As the former, after several years of anti-war agitation, Cairns led an anti-Vietnam War street march in Melbourne in 1970 that attracted 100,000 peaceful protesters. Although he lost his position as deputy prime minister by early 1975 , he continued to champion a countercultural philosophy for the rest of his life. In December 1976, prior to his resignation from politics, Cairns and his colleague Junie Morosi organised the first Down to Earth ConFest at the Cotter River Recreation Reserve, ${ }^{101}$ just south of Canberra. It attracted 10,000 to 15,000 people. Holmes, a vigorous early BRG collective member and regular exhibitor who was then living in Kurrajong Heights in the Blue Mountains, came to Canberra for the first time in 1976 to attend the festival and recalls that 'everyone was very excited about it'. ${ }^{102}$

Canberra provided a haven and a home for Holmes, who came to CSA in 1979 aged 34. Her personal journey is different to those in the student cohort who were in their early twenties, and it stands in contrast to Martin's politicised, unionised background. Holmes exemplifies the generation of women for whom the women's liberation movement provided support and for whom art provided solace and inspiration. Because the story of her journey to CSA encapsulates the experience of a particular and large group of women of similar ages and from similar backgrounds, I quote her at length:

I of course read The female eunuch. I was in a rather exploitative marriage in my twenties and left that in my thirties and went to live up in Northern NSW. I knew I was capable of a lot more than what I'd been indoctrinated as and I knew the pathway was through art. I had feminist friends in Sydney. [There was] a loose collection of women. We'd have dinner parties or go to restaurants. I read the Sydney Morning Herald advertisement for

101 ConFest was a manifestation of the Down to Earth Movement which Morosi and Cairns founded after Cairns lost his ministerial position in the Whitlam government and before his resignation from parliament. The movement folded in 1979.

102 Cherylynn Holmes, interview with the author, 30 August 2012. 
the art school and applied and got the train down to Canberra for the interview. On the way back out of town, I realised that one of my dearest friends from that first encounter [the Down to Earth ConFest in 1976] was working at the NGA and he said 'You're not getting on that train. Stay in Canberra overnight and I'll fly you back tomorrow'. He took me to dinner at Santa Lucia and we dined with Rosalie Gascoigne and her daughter. And then we went to a Vasarely exhibition in the Albert Hall. He was flying off next morning to collect some work from somewhere and a car picked us up in the morning and took us to the airport and we took separate planes. It was a magical journey to Canberra. [When I arrived to begin at CSA] I stayed with my sister for a week and somehow got into a group house briefly and then got a government house in O'Connor. ${ }^{103}$

This sympathetic environment was enhanced by the development of Ainslie Village. Opened as a military barracks during World War II, it provided accommodation for Canberra's migrant worker population after 1945 and, later, interim accommodation for migrants. From 1976 to 1980 the hostel, managed by private contractors and the DCT, provided short-term housing for migrants and those on low incomes. By 1980, years of neglect meant that buildings were in disrepair and the Village had gained a reputation for pervasive violence; those most in need were reluctant to accept emergency accommodation there. Jobless Action, whose initial support had enabled the creation of both Megalo and BRG, submitted to the DCT a joint proposal with the Salvation Army, St Vincent de Paul Society and Village residents to establish an incorporated body composed of residents and community organisations to manage the Village. The proposal was accepted and shortly thereafter, control of the Village passed to the new body. Jobless Action members comprised community workers, activists and artists, and an early decision was taken to set up Megalo in the Village.

When Megalo set up its rudimentary workshop at Ainslie Village, the anti-aesthetic ethos - which Hal Foster has defined as 'a will to grasp the present nexus of culture and politics and to affirm a practice resistant both to academic modernism and political reaction' - began to flower

103 Holmes, 2012. Holmes revealed that her friend and local wit Dennis Trigg, in the true spirit of the countercultural movement, named O'Connor as the Peoples Republic of O'Connor by which name it is still fondly known by many Canberrans. 
collectively outside of CSA. ${ }^{104}$ For a brief moment in the history of the village, the influence of European and Australian countercultural utopias manifested in a collective aesthetic. It was realised through the planting of common food gardens and particularly through the presence of a functioning creative workshop whose output was intrinsically tied to the concerns, both recreational and sociopolitical, of the Canberran subculture to which Megalo members belonged.

The cohort responsible for the birth of Megalo/BRG were themselves in an interstitial generational divide; the anti-Vietnam War protests, which attracted hundreds of thousands of protesters nationally and galvanised the previous generation, were replaced with a creeping disempowerment of a significant proportion of the Australian population. This was particularly obvious within the homogenised subcultural population in Canberra of which these young artist/activists were a part.

Coupled with their desire to make art that was recognised outside of the closed gallery system was this renewed ethos that borrowed from the 1968 European student uprisings and was influenced by the countercultural movement, the women's liberation movement, and locally rising levels of poverty and unemployment. This ethos stimulated their desire to make art that was 'useful, [art] that people needed. It was anti-individualist in that sense, anti-aesthetic in many ways and about empowering people. ${ }^{105}$

In spite of the many serious concerns that were foregrounded through prints and posters, community action for these activist artists/printmakers was often actively based in light-hearted social engagement and, for Church and others, Megalo and BRG both provided 'another place to play':

we had so much energy ... [S] ocially there was a lot of brainstorming. We were fortunate to be alive at a time when we really felt like we could do anything that we turned our hands to. And that, I suppose, was a little bit like what was happening in '68. It was an exciting time. ${ }^{106}$

Social play was boldly in evidence at the 1985 event Off the beach, for which the art deco environs of the Manuka Pool provided the frame for costumes constructed to theme by collective members (see Figures 14 and 15).

104 Hal Foster, 'Postmodernism: a preface', in The anti-aesthetic: essays on postmodern culture, Washington, Bay Press, 1983, p xv.

105 Church, 2012.

106 Church, 2012. 


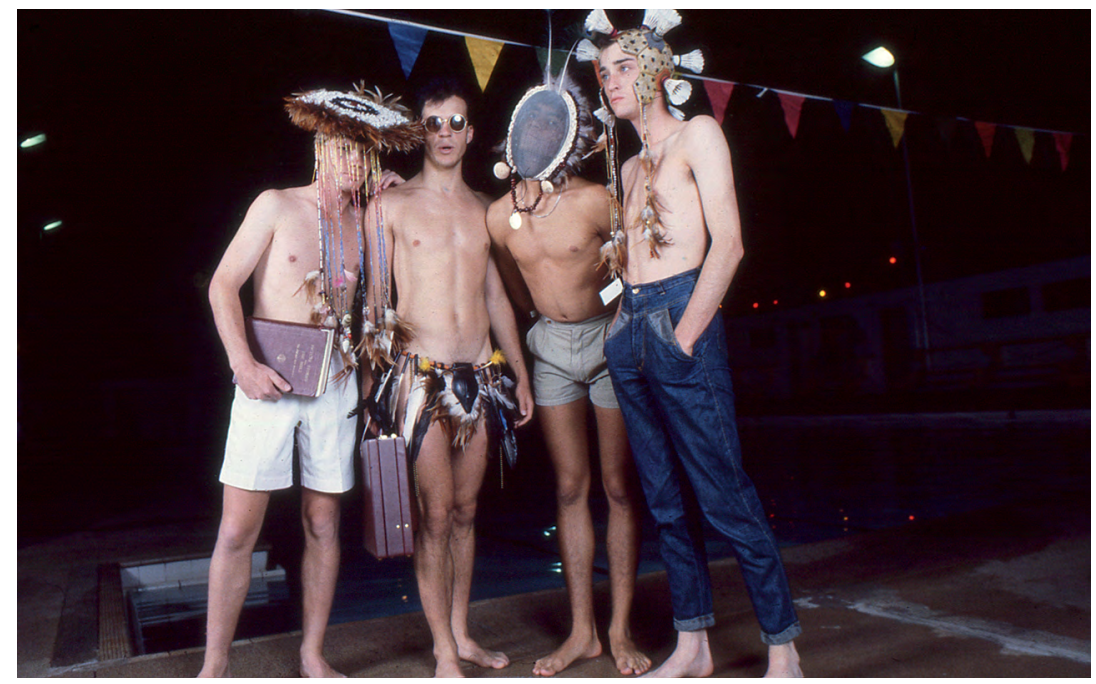

Figure 14. Collective members in costume for Off the beach, 27 February - 17 March 1985, 23 February 1985

Source. CCAS image archive, reproduced with permission

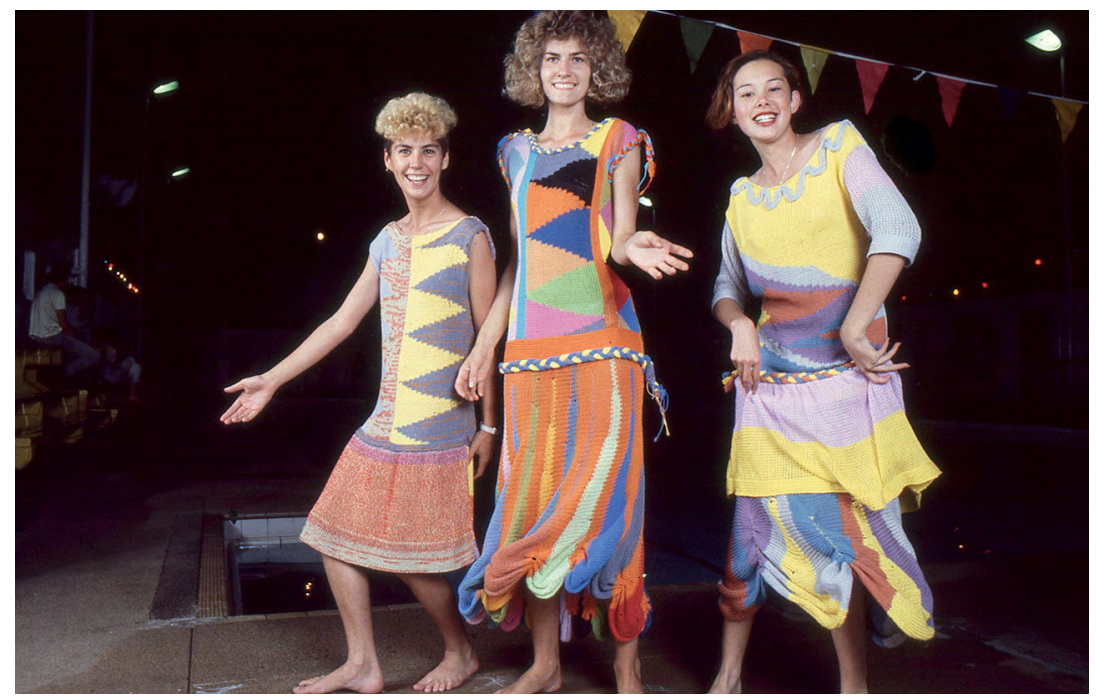

Figure 15. Collective members in costume for Off the beach, 27 February - 17 March 1985, 23 February 1985

Source. CCAS image archive, reproduced with permission 
By the early 1980s, Australians were feeling the effects of the conservative Liberal government under Malcolm Fraser. Razor gangs slashed spending on women's health and social services and, consequently, on families and the unemployed; the changed policies bit deeply into previous gains. In 1981, the Single Women's Shelter Collective was established to push for single women's crisis accommodation and, after several years of intense negotiation and following high-profile community actions including squatting, the government provided some funding to establish the Toora Single Women's Shelter in 1983, followed by the Incest Centre in $1984 .{ }^{107}$ The decrease in government support through the Fraser years led to an increase in radical expressions of the need for that support for women's services; in Canberra and elsewhere in Australia, poster makers played a pivotal role in getting these messages out into the public domain. ${ }^{108}$

Contributing to the charged political environment that came with living and working in the national capital, were older feminist women students and lecturers who arrived at CSA from other cities. They included Anne Morris who, like Binns, was an early contributor to community arts. Morris arrived at CSA in 1982 and positively influenced a number of students in the printmaking and photomedia workshops, including Church and Holmes. Holmes recalls travelling to Sydney with Morris to attend meetings for the Women's Art Register (the first of which Martin also attended), and the 1982 Women and Arts Festival: 'We thought, "Hey, there's nothing like this in Canberra", so we came back and organised an exhibition'. ${ }^{109}$ The ACG, at that time in the Wales Centre on London Circuit, hosted this exhibition of work by 28 local women artists, titled The first Super Doreen show, which Holmes curated.

107 See, Elena Roseman, 'Talking like a Toora woman: the Herstory of Toora Women Inc', Toora Women Inc, Canberra, 2004, and 'From Lady Denman to Katy Gallagher: a century of woman's contribution to Canberra', www.womenaustralia.info/exhib/ldkg/. Conversations with Lee Collins, who was an active member of $2 \mathrm{xx}$ Community Radio and a member of the young 'punk' generation of lesbian feminists active in Canberra from the early 1980s, were revealing and useful.

108 Many of the posters in BRG's first exhibition carried messages of need for women's services. Additionally, in Canberra during 1972 and 1973, the posters printed by members of CWL were entirely concerned with women's issues (Ward, quoted in Julia Ryan, unpublished notes from 'Canberra Women's Liberation: main focus: 1970-75', talk, U3A Australian History, June 2012, email to the author, 20 June 2016).

109 Holmes, 2012. 


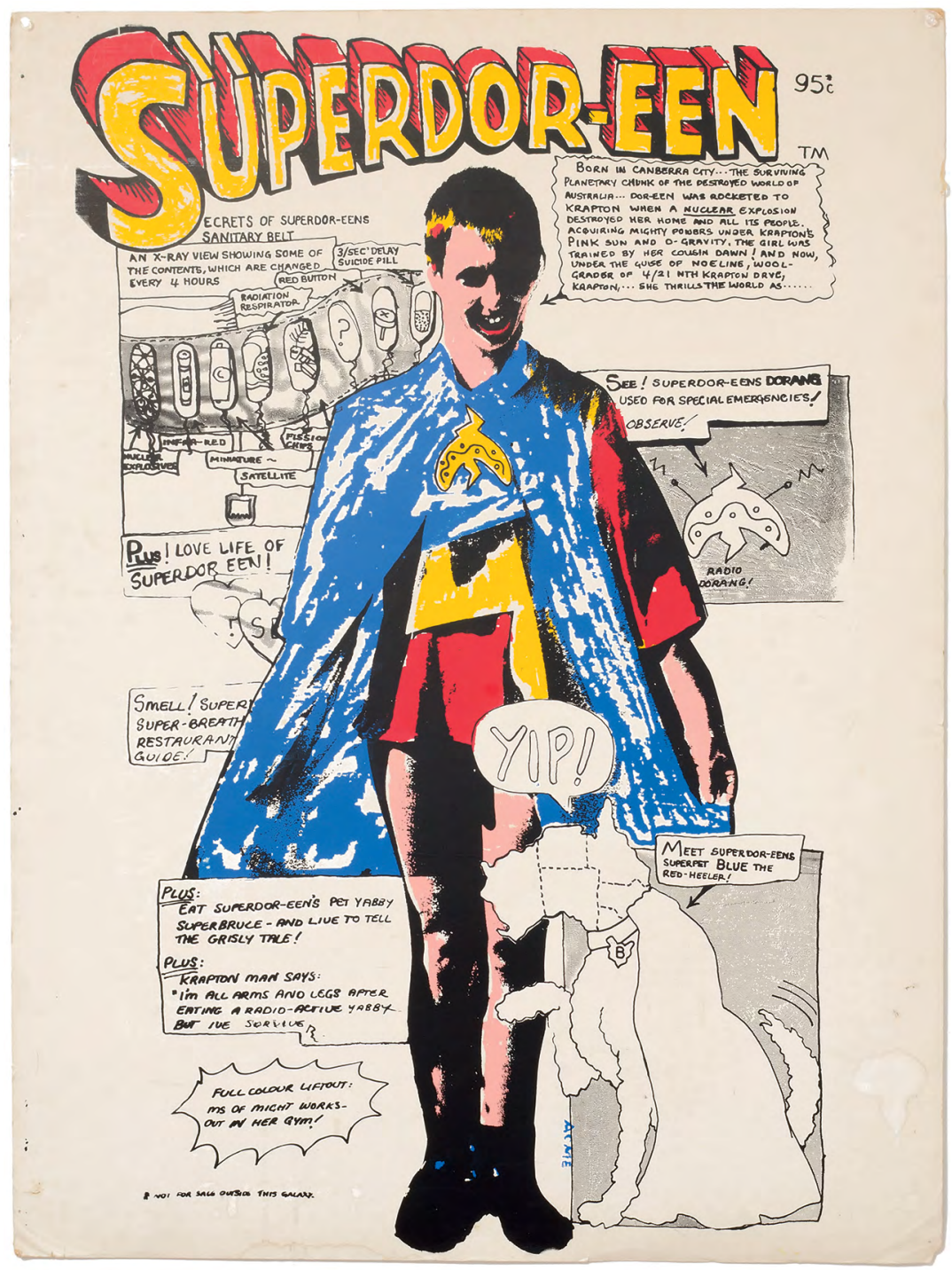

Figure 16. Julia Church, Super Doreen, 1982, poster, 102 x $76 \mathrm{~cm}$

Source. Photographer: Brenton McGeachie. Private collection, reproduced with permission 
Church, who created the cartoon character Super Doreen in early 1981 (see Figure 16), remembers Morris as:

an inspiring figure. She had already been working in community arts before us and making a living out of it. She was incredibly well-organised but also an extraordinarily open and generous person with her knowledge and ideas, and very encouraging of everybody. ${ }^{110}$

Toni Robertson joined Martin in the Printmaking Workshop between 1982 and 1985. Robertson was an early member of the Earthworks Poster Collective at the Tin Sheds, and also a founder of the Sydney Women's Art Movement. Her presence in Canberra ensured that contemporary politics continued to be a focus at CSA and also encouraged more frequent visits from her colleague Binns.

\section{Vivienne Binns}

Binns' influence in the early 1980s on the burgeoning arts community in Canberra was subtle, but she was already disposed to view Canberra as a future home, eventually relocating in 1994 from the Blue Mountains to take up a position at CSA as lecturer in foundation studies, painting, sculpture and theory. She had in fact 'been up and down to Canberra'111 since her 1975 and 1976 exhibitions at Fantasia and Abraxas Galleries respectively:

Even with the women's art movement, back in the seventies when we formed groups in Sydney, we visited other states, searching out women artists. We'd made contact [in Canberra with] people like Rosalie Gascoigne and so on and I'd had fleeting visits with the place through the community arts, enough that I knew there was theatre and arts and the poster [movement]. There have always been lively activities and projects going on ... I always knew there was a community [of women artists]. ${ }^{112}$

Canberra's strong community arts focus, recognised by Binns in the 1970s, was a clear reason for her growing interest in the city. By the time she settled permanently in Canberra, her experiences in this area assisted in maintaining the political focus of CSA students throughout the 1990s and 2000s.

110 Church, 2012.

111 Vivienne Binns, interview with the author, 26 February 2012.

112 Binns, 2012. 
Binns' 'explosive' debut 1967 exhibition at Watters Gallery in Sydney is now generally seen as anticipating the rise of 1970s feminist art in Australia. ${ }^{113}$ By the early 1970s, her fascination with craft and feminism was coalescing into what would become more than a decade of fertile engagement with community arts in both urban and rural women's communities, beginning with the travelling community arts project Artsmobile in 1972. Her best-known project from the period is Mothers' memories others' memories (MMOM) (1979-81), which focused on creative expression in the lives of women in Sydney's Blacktown area. The benefits experienced by a wide range of women as a result of their involvement in $M M O M$ - and Full flight (1981-83), which was enacted in central and far-west New South Wales - was recognised with Binns award of an Order of Australia medal in 1983 for services to art and craft. ${ }^{114}$ She is acknowledged as a founding member of the Women's Art Movement, a pioneer of community arts practice, and an enduring and effective advocate for women artists. Illustrating the latter is the following extract from Binns' 1977 letter to the Craft Council of NSW:

The argument for excellence in arts is hard to dispute and because of this it is itself excellent as a subterfuge to disguise other motives. It is used for instance to disguise embedded sexual discrimination in job selection at some art colleges. It can be used to disguise a situation which by means of special selection criteria fosters and nurtures the needs of a few in the name of 'high standards'. It can be the death knell of creativity in the widest sense and blind people to a narrow view of what art is. Our view is already heavily blinkered. ${ }^{115}$

113 Deborah Clark's use of the word 'explosive' reflects the response of contemporary critics for whom the sexual imagery of the works, particularly coming from a young female artist, was entirely unexpected. Clark writes that 'this show marked a key moment in the nascent Women's Art Movement' (Deborah Clark, 'The painting of Vivienne Binns', in Craig Judd (ed), Vivienne Binns, exhibition catalogue, Hobart, Tasmanian Museum and Art Gallery, 2006, p 8).

114 Of Full flight, Binns wrote, 'As an Artist in Community in a large predominantly rural area of 60,000 square miles and a population of 200,000, I travel from town to town in a caravan which has living quarters and a small work space. I stay for $2-4$ months in each place and visit small isolated towns as well as cities in the area. I see my role in Full Flight as that of an art worker travelling the country getting to know other art workers with whom I share, and who share with me experience, knowledge, ideas, skills, work projects and friendships' (Maria Kunda, 'The artist, the community, the land', in Judd, 2006, p 20).

115 Penny Peckham, 'Vivienne Binns biography', in Judd, 2012, pp 30-41. 
Binns agreed with Martin's earlier assessment of Canberra as 'a breath of fresh air'. In 1993, at the tail end of a Keating Fellowship, Binns travelled again to Canberra to take up a residency in the Painting Workshop at CSA and later explained:

I just found the CSA such a fabulous place by comparison to the politics and unpleasantness of the other major cities like Sydney and Melbourne where I might look for work [that] I sort of pestered them to give me a job. I knew there were people who were really happy to have me coming there. ${ }^{116}$

Canberra, therefore, was seen to be free of the pervasive art world politics - as identified by Sellbach, Martin and Binns - that characterised life in the southern Australian capitals from which these important practitioners came. ${ }^{17}$

\section{Slut}

In the middle of 1983, Alder, on behalf of the BRG collective, took receipt of a consignment of works on paper from the Jill Posters collective in Melbourne. Among them was Slut. Tellingly, it would prove to be the only poster ever rejected by the collective. Slut, now in the print collection at the National Gallery, differs markedly in two key respects from other posters in the gallery's collection from the period of $1983 / 84 .{ }^{118}$ Firstly, it is printed on fine art paper in only two colours, blue and red. Secondly, and most significantly, the central figure, a woman, has long red hair and wears a red dress and red stiletto shoes. A thought bubble reads 'I won't see you in Paradise'. At the bottom right of the poster, a small clock shows five minutes to midnight; the text on the left of the clock face reads 'nuclear time'. Entering from the centre left, beginning outside the poster frame, is a quick rendering of a cruise missile, pointing at the figure and bearing the word 'slut'. Finally, the figure is fully outlined with a cut line in black from the knees up and the written exhortation to 'cut here' (see Figure 17).

116 Binns, 2012.

117 Canberra is still noted for its warm, inclusive and supportive arts community, particularly the local organisations CCAS, CMAG, M16, Megalo, Photo-Access and ANCA.

118 Roger Butler purchased the Slut poster to add to the National Gallery's collection of posters from BRG, Jill Posters and other Australian printmaking collectives, including, from 1973, 'almost a complete collection' of the Earthworks Poster Collective (Roger Butler, quoted in 'Posters for posterity', Canberra Times, 4 September 1986, p 1s). 


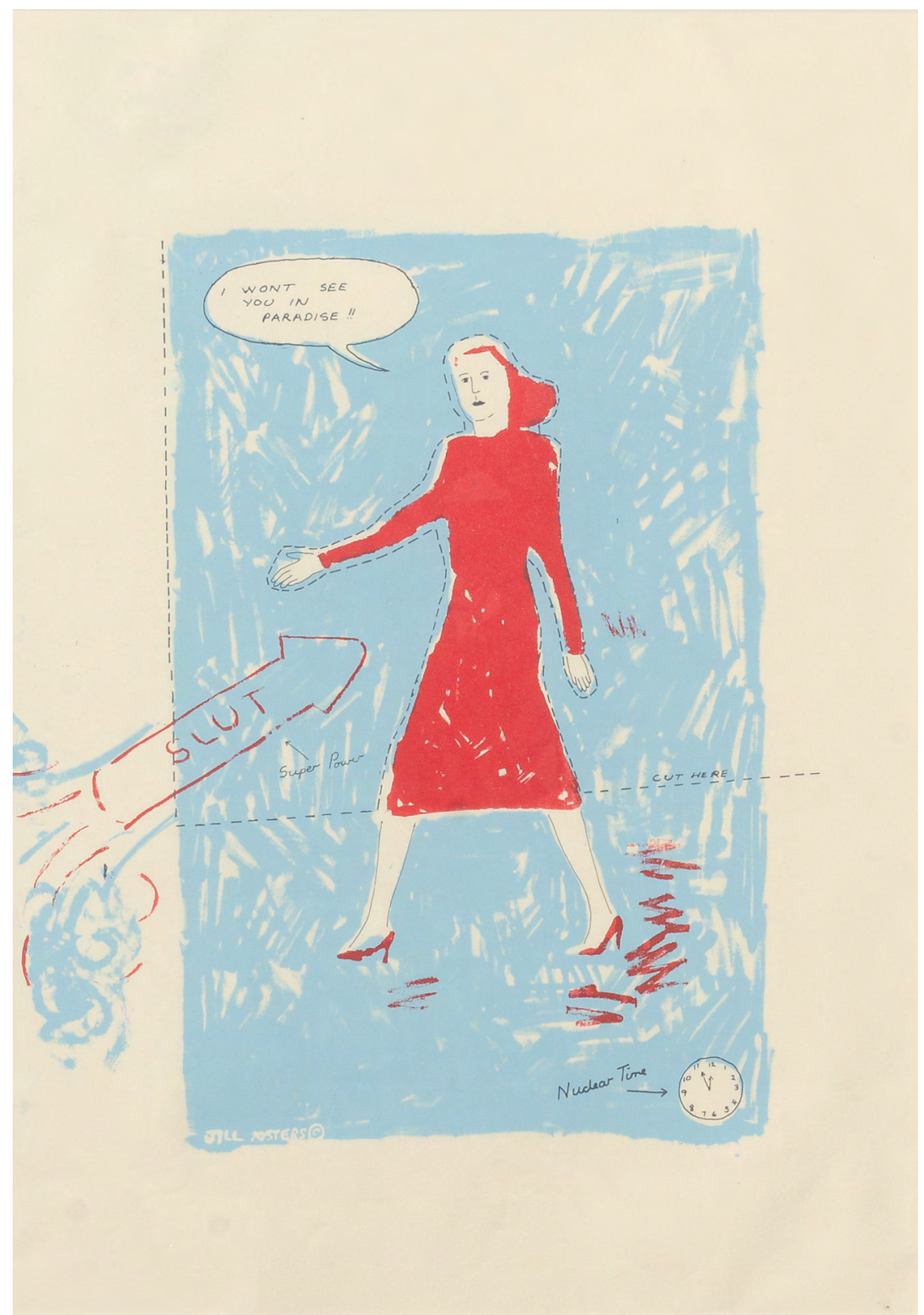

Figure 17. Catriona Holyoake, I won't see you in paradise (s/ut), 1983, screen print, $100 \times 80 \mathrm{~cm}$

Source. Collection of the National Gallery of Australia. Photograph by Brenton McGeachie, CCAS image archive, reproduced with permission 
Canberra's principal position as a fulcrum of political decision-making and social activism and as a nexus for the national expression of aspects of the women's liberation movement, among other social movements of the 1970s and 1980s, has been established. The strong feminist leanings of CSA student and graduate printmakers, Martin's role and the influences of community arts practitioners such as Binns and Morris, are clear. Given these facts, the 1983 rejection of Slut indicates that other factors were at play in Canberra's emerging contemporary arts scene. Among them was a continued emphasis on second-wave feminism, which Martin's Maoist political background may have subtly encouraged. Additionally, Canberra's status as a relatively isolated regional centre meant that collective members were less exposed to those early visual examples of third-wave feminism.

Alder's final day as coordinator of BRG was 11 August 1983. Her secondlast letter, written on that day, was to the Jill Posters collective:

Received your posters the other day and feel I must write to tell you that I don't feel the gallery can have the 'slut' poster in its racks. I realise that this poster has many intentions and that whoever did it hopefully meant to put across a message of 'super powers = penis [leads to] oppression of women'. However, visually that message is not clear and the poster puts across an extremely negative image. My main argument is that the woman is portrayed as a totally passive helpless victim. Personally I find this very offensive. Women must be made aware of the negative aspects of our society but at the same time as commenting on this oppression women must give other women positive models to act upon. I find that this is not the case in this instance. Please let me know what you think, and I look forward to hearing from you. Yours sincerely, Alison Alder for Bitumen River. ${ }^{119}$

On 24 November 1983, Colin Russell wrote to Jill Posters in his capacity as temporary coordinator. Having carried out a BRG stocktake of posters, postcards and books, Russell acknowledged receipt of three lots of five posters, and sought clarification as to whether the BRG commission should be added on to the poster price of $\$ 3.75$ or deducted from it. ${ }^{120}$ The letter also enclosed copies of Slut that Alder and Russell agreed could not be carried by BRG due to its 'ambiguity and its negative projection':

119 Alison Alder, letter to Jill Posters, 11 August 1983.

120 The reply from Jill Posters indicates that galleries in Melbourne added 25 per cent to take the retail price to $\$ 5.00$. BRG had been adding 20 per cent on for a price of $\$ 4.50$. 
Also enclosed are posters that had been sent to us about three or four months ago. At that time Alison, who was the co-ordinator, sent a letter expressing her misgivings towards that poster and if it would be suitable for the gallery to have placed it in our racks, mainly for reasons of ambiguity and its negative projection. She had written with the intention of finding out how you felt and personally as a postermaker myself, I supported her on this point. Since we received no reply and a stocktake was under way, the collective, at a general meeting, decided that the 'slut' poster not be exhibited, and be returned to the Jillposters collective. I hope that you don't view this as a harsh action or that any prejudices against the intended meaning of the work are being enforced. ${ }^{121}$

A very informal note came back from Carole Wilson, a founding member of Jill Posters:

Colin darling you are oh so formal, yes we are horrendously offended by the fact that you didn't display the 'slut' poster and we are planning to execute a subversive, terrorist action on Bitumen River Gallery and especially you.

The letter, succinctly displaying the ad hoc nature of the small Australian print collective, continued:

Thank you for being so terribly tactful \& polite - I'm usually the only one who reads Jill Posters mail anyway ... Jillposters couldn't possibly get itself together enough to write a reply to Alison's letter. Very strange collective we have lots of money $\&$ no one prints posters; we are given a free workshop \& we give it back; etc, etc. ${ }^{122}$

Russell appended a note to the Jill Posters letter before filing: ' $\mathrm{Ha} \mathrm{Ha}-$ personal friend not to be taken as a need for military armament! Colin'.

As already noted, the BRG collective determined at the outset that the only requirement for work to be accepted for exhibition was that it be non-sexist and non-racist. Slut was clearly non-racist and therefore Alder's reasons for rejecting the poster centred on constructions of female sexuality. Her objections to the poster - that it put across 'an extremely negative image'; that the woman 'was portrayed as a totally passive victim'; that she, Alder, personally found it 'very offensive'; and that 'women

121 Colin Russell, letter to Jill Posters, 24 November 1983. Original emphasis.

122 Carole [now known to be Carole Wilson], letter to Colin Russell, Tuesday (undated), 1983, CCAS archives. 
[in this case, poster makers] must give other women positive models to act upon', which she felt this poster did not do - speak to the image of woman in second-wave feminism as constructed by issues of equality.

This construction eschewed references to femininity; beauty, inextricably linked to objectification, was to be avoided. The 1984 Post-atomic card, produced for the Campaign for International Co-operation and Disarmament, illustrates this type of representation of women in antinuclear posters. Printed in four colours, including a radioactive green/ yellow, its two female workers are dressed in overalls and boots and wielding shovels, with a banner that reads 'Bury it Mac' (see Figure 18). ${ }^{123}$

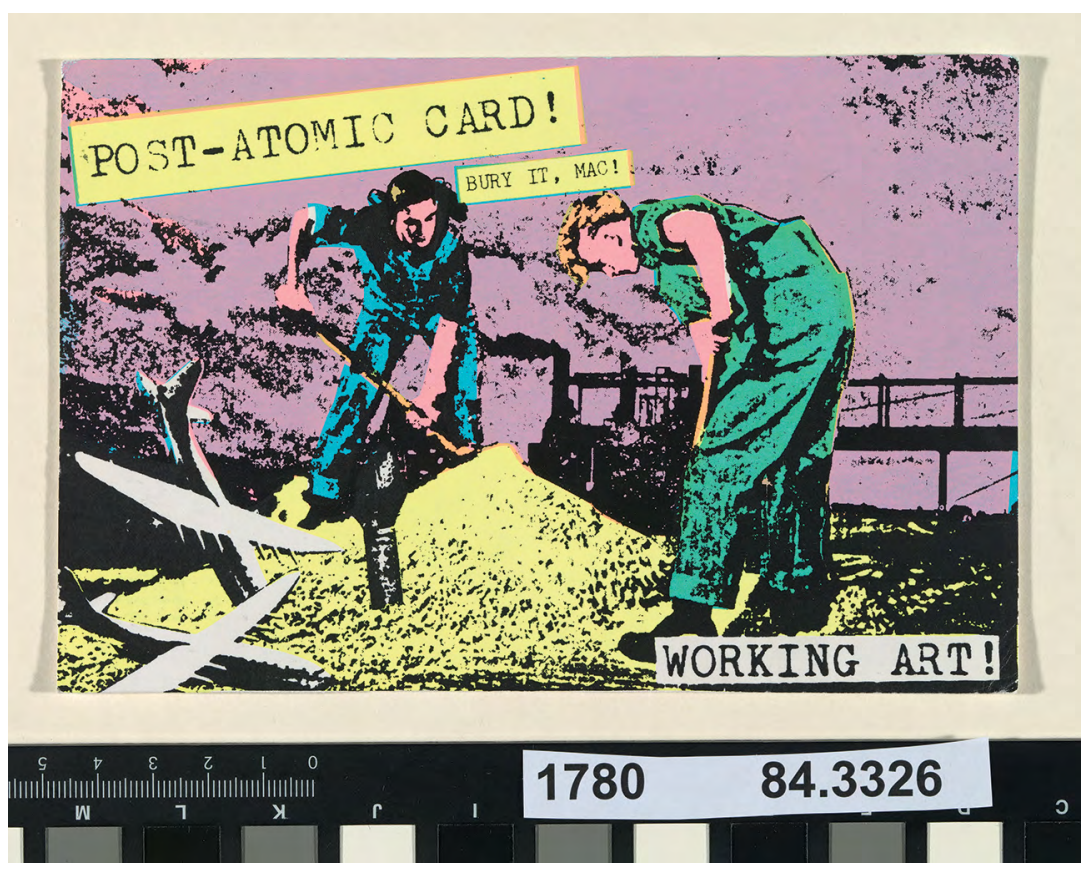

Figure 18. Post-atomic card!: Working art!, colour postcard

Source. Designed and printed by the Fallout Committee for the Post-atomic postcard show, 1984. Collection of the National Gallery of Australia, reproduced with permission

123 Anti-nuclear posters were produced at all poster-making collectives in the early 1980s, encouraging and encouraged by the Women's Peace Camp and protests at Pine Gap in the Northern Territory in 1983. 'Feminists in Australia pioneered new forms of activity in opposition to USA bases, uranium mining and the threat of nuclear war' (Joyce Stevens, 'The nineteen seventies and eighties continued', A history of International Women's Day in words and images, www.isis.aust.com/ iwd/stevens/70s80s_3.htm, accessed 14 May 2012). 
The blatant femininity of the Slut poster's protagonist - her long red hair, red dress and red stiletto shoes - was in stark opposition to these representations. Red was a colour still associated with female sexual promiscuity, with the term 'scarlet woman', and a general sense of moral laxity inherent in the potent combination of colour and stilettos. If Holyoake's woman had been wearing boots and overalls, the poster may have passed. But Alder was herself a second-wave feminist and the collective, inclined by virtue of political and social choices to walk the feminist talk, were unable to accept this construction of the feminine as anything other than a weak or 'passive' sexual stereotype.

The collective may also have been influenced by what Laura Meyer has identified as the 'heavy fire' that key feminist art strategies came under in the 1980s. The feminist art movement began with the Fresno Feminist Art Program at Fresno State College (now University) in California's San Joaquin Valley in 1970 under visiting artist Judy Chicago. Meyer identifies two of its main 'pedagogical artmaking strategies' as 'the quest for new kinds of female body imagery, or so-called cunt art' and the use of 'female media', which - under the rubric of 'women's work' - included performance art, photography, filmmaking, needlework, and the use of costume and make-up. Meyer posits that, by the 1980s, these formerly key strategies were seen to be negatively 'reinforc[ing] an essentialist [or in other words a collection of fixed traits] view of women'. ${ }^{124}$ Despite the fact that words such as 'slut' and 'cunt' had gained widespread currency through the female art movement and the women's liberation movement of the 1970s, they nonetheless retained a seedy pejorative quality; the collective would have been hard-pressed not to identify the use of 'slut' in this instance as essentialising.

It was not until the early 1990s and the rise of 'lipstick feminism' that feminism and femininity were seen to cohabit, evidenced publicly through the use of make-up and the wearing of dresses and high heels. Additionally, the use of female-centric language such as 'slut' and 'cunt' was widely reclaimed by women in the 1990s as potent symbols of personal power. 
In Australia, the cyberfeminist ${ }^{125}$ collective VNS Matrix (1991-97) is credited with launching the cyberfeminist movement - which is charged with examining the multiple intersections between women and computer technologies - that made this reclamation of language visible, referring to themselves in their 1991 manifesto as 'the modern cunt' pitted against the referent of 'big daddy mainframe' in the continuing war against patriarchy. ${ }^{126}$ Despite the coming changes, language, as it applied to gender and sexuality in the early 1980s, was essentially neutralising: Alder's reading of the poster, as 'super powers = penis [leads to] oppression of women', is a response that is indivisibly tied to the constructions of second-wave feminism.

Arguably, the BRG collective's response says more about the nature of the engagement with feminism in Canberra and the heightened politicisation inherent in the national capital than it does about the wider national and international feminist movement. In other words, Alder's and the collective's response may have been more politically charged, by virtue of being located at the centre of Australia's political decision-making, than Holyoake anticipated. This would therefore reflect a disconnect between the Melbourne-based artist and the Canberra collective and thus between the politically heightened but, at the same time, relatively more insular art world of Canberra and that of the more established scene in Melbourne. Additionally, during the early 1980s, the BRG collective largely comprised

125 Cyberfeminism arose in 1991 with artist collective VNS Matrix in Australia and in 1992 with philosopher Sadie Plant in the United Kingdom. Both built on the initial work of US scholar Donna Haraway in her 1985 article, 'The cyborg manifesto: science, technology and socialist feminism in the late twentieth century' (in David Bell and Barbara M Kennedy (eds), The cybercultures reader, London, New York, Routledge, 2000, pp 291-324). In 'Cyberfeminism(s): origins, definitions and overview', Vesna Dragojlov gives a comprehensive examination of cyberfeminism's history and argues that, broadly speaking, cyberfeminism's main goal 'has been to analyze issues of gender, new technologies and, especially, the internet' (25) that 'sit at the crossroads of art, theory and activism' (23) (University of Advancing Technology, www.uat.edu/webmedia/pdf/Cyberfem_14066.pdf, accessed 24 June 2012, site discontinued).

126 VNS Matrix's manifesto reads as follows:

\section{CYBERFEMINIST MANIFESTO FOR THE 21ST CENTURY}

We are the modern cunt / positive anti reason / unbounded unleashed unforgiving / we see art with our cunt we make art with our cunt / we believe in jouissance madness holiness and poetry / we are the virus of the new world disorder / rupturing the symbolic from within / saboteurs of big daddy mainframe / the clitoris is a direct line to the matrix / VNS MATRIX / terminators of the moral codes / mercenaries of slime / go down on the altar of abjection / probing the visceral temple we speak in tongues / infiltrating disrupting disseminating / corrupting the discourse / we are the future cunt.

Manifesto first declared by VNS Matrix1991, Adelaide \& Sydney, Australia (www.sterneck.net/cyber/ vns-matrix/index.php, accessed 24 June 2012). 
present and past students from CSA who were influenced by the emphasis on emancipation inherent in Martin's Marxist/Maoist Adelaide background. It can therefore be argued that the politics of second-wave feminism was a driving force in the context of the collective's view of Slut rather than the changing constructions of feminism emerging in southern capitals. Melbourne artists on the other hand were arguably more exposed, through the rapidly increasing movement of artists and ideas in and out of the country, to European and North American trends, which included the theories and practices of third-wave feminism. ${ }^{127}$

Holyoake was a member of the Jill Posters collective that, for a time, included former BRG members Church, Walters and Deej Fabyc, all of whom moved to Melbourne in 1983. Like Martin and Binns, Church regarded Canberra as a centre where political orthodoxy held less sway. As an activist printmaker who was heavily involved in CSA's scene from 1979 to 1982, a member of the loose network of underground printers in Canberra, a founding member of Megalo and BRG, and then as a founding member, along with Kath Walters, of several print workshops in Melbourne from 1983 onwards, ${ }^{128}$ Church later reflected:

I think in Canberra there was more flexibility, there was less political orthodoxy. In Melbourne and Sydney I think there was a lot more orthodoxy and you could get into some really terrible stoushes. I'm just thinking about Jill Posters for example which had all sorts of political problems because people held very strong political positions; they were polar opposites sometimes or imagined that they were. I think Canberra was quite liberating in that way. ${ }^{129}$

127 This may seem unlikely today when images and movements are instantaneously transferred across borders. Movements grew more slowly in the early 1980s in the absence of email and internet. 128 Julia Church and Kath Walters arrived in Melbourne from Canberra at the beginning of 1983. Church immediately set up Bloody Good Graffix at University of Melbourne where the duo printed and taught printmaking skills to community members. Church recalled that 'Bloody Good Graphics became one of the base camps for Jill Posters. Contemporaneously we applied for a grant to set up Another Planet and for a Victorian Department of the Arts Community Arts Grant and got both. So [with the latter] we worked with the Hospital Employees Federation creating banners for them and going out as roaming artists-in-residence creating visual [material] with their membership. That was a really interesting period of time. Then we employed people to set up Another Planet and some of those people came from [Canberra including] Diana Wells and Julie Shiels who'd been involved in Jill Posters' (Church, 2012).

129 Church, 2012. 
Many Jill Posters members were lesbian separatists, although Holyoake 'was heterosexual, liked men, liked having sex with men'. ${ }^{130}$ Holyoake was the same age as her Megalo/BRG contemporaries but was both subject to and took advantage of a more diverse social and artistic milieu. While others 'tended to work in their groups', Holyoake 'mix[ed] about with a lot of different groups', including Melbourne's Clifton Hill art community and other groups making films and music. Friends and 'artist feminists' returning to Melbourne from visits to the United Kingdom and New York were inspired by emerging pop-cultural feminist icons in fashion - such as Vivienne Westwood - and music, such as Madonna. "Red lipstick was "in" - sluttish-ness was out there, female sexuality was definitely being pushed into the mix in the early 80s. ${ }^{3131}$ Also emerging in Europe at the time was New Romanticism and Holyoake recalled wanting to 'dress up in 50 s-60s retro feminine'.

Holyoake embraced these many and diverse influences and crafted a poster that proved unacceptable to the BRG collective and difficult to accept, even for her more internationally influenced Melbourne contemporaries. Despite the fact that Holyoake characterises early 1980s Melbourne as 'a post-feminist/post-punk era' during which she and other women peers 'reacted to and questioned the exclusivity' of hard-core feminist ideas including the benefit of following masculine forms of dress - it is clear that the central female figure in Slut presents a construction of 'woman' that was unusually feminine within the context of imagery favoured by a second-wave feminist collective such as Jill Posters. ${ }^{132}$

Jill Posters collective members were primarily printing posters to be pasted up in the street, occasionally working in two colours, which allowed the poster makers to maximise limited printing time and funds and suited the postmodern use of photographic images. Artist and founding Jill Posters member Wilson secured access to the print room at University of Melbourne, where Slut was printed out of hours. ${ }^{133}$ It was here also that

130 Catriona Holyoake, email to the author, 24 December 2011. Jill Posters members included Lesley Baxter, Ally Black, Linda Brassel, Church, Zana Dare, Fabyc, Maggie Fooke, Julie Higginbotham, Holyoake, Barbara Miles, Kate Reeves, Linda Rhodes, Julie Shiels, Lin Tobias, Julia Tobin, Walters, Wilson.

131 Holyoake, 2011.

132 Holyoake, 2011.

133 I am grateful to Carole Wilson, formerly of Jill Posters, who remembered Holyoake as the Slut poster maker and set me on the path to finding her. I was then able to attribute the poster in the NGA collection. Holyoake has taught digital media at RMIT for 15 years and is currently the senior digital strategist for Red Cross Blood Service in Melbourne. 
the Jill Posters' printmakers made small editions on quality paper for their portfolios. Holyoake writes that 'A lot of the work I did at this time was based on a simple illustrative style - juxtaposing images to create a story or project an idea..$^{134}$

Holyoake's central female figure was a photographic image of a woman striding across a street, taken from Vogue magazine. The image appealed to her as it was:

a positive active image for a fashion magazine, which usually shows women as the object. [The model] was one of my favourites and I really liked the dress; it was very simple and elegant. I was a bit of a chameleon—overalls one day and skirts and heels the next ... you had to blend in when required. ${ }^{135}$

Slut, with its appropriation of this photographic image and its gathering of messages and images from the immediate contemporary milieu, can be seen as a deployment of Julia Kristeva's 'fragmentation of the imaginary', which Kristeva identified as a marker of postmodernist art strategies. ${ }^{136}$ Holyoake was, therefore, exquisitely of her time, elaborating in Slut the 'real mix of feminist and postmodern theory' to which she was exposed. ${ }^{137}$

Alder's initial reading of the poster's message - that is, that 'super powers $=$ penis [leads to] oppression of women' - was at odds with the artist's intentions. As Holyoake remembered it:

I was trying to subvert the penis by making it look like a toy rocket (silly boy missile) in relation to the woman in red who is striding out confidently - separate and oblivious of the rocket ... it's half rocket half penis. I was trying to make fun of it (Germaine Greer style). It's just a penis! - Boys and their toys, men and their rockets. The cut out is to add to the idea that this is a game and yes we can change the play. ${ }^{138}$

And, indeed, if the cut line were to be employed and the figure pulled forward out of the poster frame, then the rocket/penis, on a trajectory towards the model's midriff, would simply pass by into open space.

134 Holyoake, 2011.

135 Holyoake, 2011.

136 Julia Kristeva, in 'Interview with Catherine Francklin', part VIIIA, 'The critique of originality', in Charles Harrison and Paul Wood (eds), Art in theory: 1900-2000: an anthology of changing ideas, Blackwell Publishing, 2003, p 1055.

137 Holyoake, 2011.

138 Holyoake, 2011. 
In the 30 years since the poster was made, the word 'Paradise', when combined with the sexualised image of woman, calls up fallout from nuclear activity in the Pacific Islands or Islamic extremist definitions of Paradise. In fact, Holyoake's use of 'Paradise' in the thought bubble was designed to be ambiguous: constructed as a series of comments on perceptions of female sexuality and the threat of nuclear holocaust. The artist's intended readings included firstly, 'I've sinned, I'm a slut (in the conservative male sense of the word), I won't get to heaven [as in the Judeo-Christian construction of paradise] and I don't care I'm having a great time'. And, secondly, 'Paradise; I won't see you there because we will be dead and the world/nature/ beauty will be destroyed'. ${ }^{139}$

Even in her hometown of Melbourne, a city subject to the ebb and flow of artists and ideas moving rapidly between Australia, America and Europe, Holyoake's collective struggled with the blatant femininity of the poster's protagonist. Reflecting in 2011 on the reception of the poster from other Jill Posters members, Holyoake - describing herself as 'deliberately trying to take a more Warholian/post-modernist tack' - wrote:

I think the reading of the poster was that it was offensive to women as in sexist. Carole Wilson was at least prepared to listen and out of friendship agreed we should still post it up in the street ... I did remember being disappointed that the poster didn't fit with what was PC [politically correct]. Failure more on my part I thought to not meet the criteria. But I have to say I do remember thinking that a lot of the PC art was really dull and that some PC people were already being a bit colloquial. So the Vogue magazine image was, I thought, going to have more impact; [in that the woman at the centre of the poster was] a civilian rather than a feminist. [I thought] no-one is going to care about a feminist in boots and overalls, people hated them. ${ }^{140}$

The rejection of Slut in Canberra, in an environment that was noted more for flexibility than for political orthodoxy, illustrates the critical importance of artists' access to diverse influences and opinions. While the proposed public display of the poster created disquiet among some members of Jill Posters, Melbourne afforded greater access to rapidly changing international constructions of, in this case, feminism and allowed for an acceptance, albeit somewhat grudging, of Slut's message. 
Canberra's contemporary artists, particularly as evidenced through BRG, were distinctly less impacted by the flood of disparate internationalist ideas that were making their way through southern capitals.

The decision to reject Slut occurred in what is now categorised as a postmodernist, post-feminist era. Arguably this brief period in the early 1980 s could be understood not as post-feminist but as an interstitial moment; between second- and third-wave feminism and, importantly, as the 1980s unfolded, between the death of the artist-run space and the birth of more highly administered art centres, in Canberra, nationally and internationally. 
This text is taken from How Local Art Made Australia's National Capital, by Anni Doyle Wawrzyńczak, published 2020 by ANU Press, The Australian National University, Canberra, Australia. doi.org/10.22459/HLAMANC.2020.04 